\title{
Role of indoor aerosols for COVID-19 viral transmission: a review
}

\author{
Bo Chen ${ }^{1,2} \cdot$ Puqi Jia ${ }^{1} \cdot$ Jie $\operatorname{Han}^{2}$ (D
}

Received: 18 December 2020 / Accepted: 23 December 2020 / Published online: 13 January 2021

(c) The Author(s), under exclusive licence to Springer Nature Switzerland AG part of Springer Nature 2021

\begin{abstract}
The relationship between outdoor atmospheric pollution by particulate matter and the morbidity and mortality of coronavirus disease 2019 (COVID-19) infections was recently disclosed, yet the role of indoor aerosols is poorly known. Since people spend most of their time indoor, indoor aerosols are closer to human occupants than outdoors, thus favoring airborne transmission of COVID-19. Therefore, here we review the characteristics of aerosol particles emitted from indoor sources, and how exposure to particles affects human respiratory infections and transport of airborne pathogens. We found that tobacco smoking, cooking, vacuum cleaning, laser printing, burning candles, mosquito coils and incenses generate large quantities of particles, mostly in the ultrafine range below $100 \mathrm{~nm}$. These tiny particles stay airborne, are deposited in the deeper regions of human airways and are difficult to be removed by the respiratory system. As a consequence, adverse effects can be induced by inhaled aerosol particles via oxidative stress and inflammation. Early epidemiological evidence and animal studies have revealed the adverse effects of particle exposure in respiratory infections. In particular, inhaled particles can impair human respiratory systems and immune functions, and induce the upregulation of angiotensin-converting enzyme 2, thus inducing higher vulnerability to COVID-19 infection. Moreover, co-production of inflammation mediators by COVID-19 infection and particle exposure magnifies the cytokine storm and aggravates symptoms in patients. We also discuss the role of indoor aerosol particles as virus carriers. Although many hypotheses were proposed, there is still few knowledge on interactions between aerosol articles and virus-laden droplets or droplet nuclei.
\end{abstract}

Keywords Coronavirus $\cdot$ SARS-CoV-2 $\cdot$ Airborne $\cdot$ Particulate $\cdot$ Ultrafine $\cdot$ Carrier $\cdot$ Air pollution

\section{Introduction}

The coronavirus disease (COVID-19) is poised to become the largest pandemic on record since the 1918 flu pandemic. As of 17 December 2020, a total of 72.6 million cases of infections including over 1.6 million deaths have been confirmed in 220 countries/areas/territories due to the pandemic (WHO 2020a). Despite some earlier debate (Lewis 2020; Morawska and Milton 2020; WHO 2020b),

Puqi Jia

jpq@1zu.edu.cn

$\bowtie$ Jie Han

jiehan@xjtu.edu.cn

1 Department of Environmental Science and Engineering, College of Earth and Environmental Sciences, Lanzhou University, Lanzhou 730000, People's Republic of China

2 Department of Environmental Science and Engineering, Xi'an Jiaotong University, Xi'an 710049,

People's Republic of China airborne transmission has been recently recognized as an effective route of transmission of COVID-19. In a scientific brief issued on July 9, 2020, the World Health Organization (WHO) acknowledged that short-range airborne transmission of COVID-19 may exist in indoor settings with poor ventilation (WHO 2020b). On October 5, 2020, the U.S. Centers for Disease Control and Prevention (CDC) changed their stance and for the first time, acknowledged airborne transmission via small droplets and particles as an important route of virus spread in the current pandemic (CDC 2020).

According to an earlier definition by the WHO, airborne transmission is defined as the spread of droplet nucleithe residue of dried respiratory aerosols $(\leq 5 \mu \mathrm{m}$ in diameter) that results from evaporation of droplets coughed or sneezed into the atmosphere or by aerosolization of infective material (WHO 2014). More recently, van Doremalen et al. (2020) tested the stability of SARS-CoV-2 (severe acute respiratory syndrome coronavirus 2 ), the causation agent of the COVID-19 pandemic, on aerosols at $21-23^{\circ} \mathrm{C}$ and $65 \%$ relative humidity. The study found that SARS-CoV-2 
remained viable after $3 \mathrm{~h}$ and the infectious titer reduced from $10^{3.5}-10^{2.7} \operatorname{TCID}_{50}$ (median tissue culture infectious dose) per liter of air. Under similar environmental conditions (i.e., $23 \pm 2{ }^{\circ} \mathrm{C}$ and $53 \pm 11 \%$ relative humidity), Fears et al. (2020) further showed that SARS-CoV-2 viruses on respirable-size aerosols maintained their infectivity and virion integrity after $16 \mathrm{~h}$.

The prolonged survival of SARS-CoV-2 on aerosol particles raised questions on whether atmospheric particles, including fine particulates in outdoor environments and indoor particle emissions could facilitate the dispersion, transport, and the persistence of the novel coronavirus (He and Han 2020; Mahabee-Gittens et al. 2020; Tang et al. 2020). In the latest public guidance, the CDC pointed out that COVID-19 can be spread by airborne transmission in enclosed spaces that have inadequate ventilation, where infectious small droplets and particles can remain suspended for minutes to hours in air and travel far from the sources (CDC 2020). Several recent studies have found strong positive correlations between atmospheric particulate levels and the local infection of COVID-19 as well as symptom aggravation in patients (Fig. 1). For instance, Yao et al. (2020) analyzed the relationship between particulate matter (PM) concentration and COVID-19 case fatality rates in 49 Chinese cities using Global Moran's I and multivariate linear regression. The results showed that fatality rates increased by $0.24 \%$ with every $10 \mu \mathrm{g} \mathrm{m}^{-3}$ increase in the $\mathrm{PM}_{2.5}$ level (i.e., particulate matter in air that are $2.5 \mu \mathrm{m}$ or less in diameter). Similar conclusions were drawn by $\mathrm{Wu}$ et al. (2020), who conducted a nationwide cross-sectional study in the United States and reported that an increase of $1.0 \mu \mathrm{g} \mathrm{m}^{-3}$ in $\mathrm{PM}_{2.5}$ correlated with an $8 \%$ increase in COVID-19 fatality rates. In an investigation in Milan metropolitan area, researchers investigated the potential association between the degree of accelerated diffusion, PM pollution, and morbidity of COVID-19. The study found that the local daily new cases were positively related with the PM, and proposed that outdoor atmospheric particulates may be possible routes of SARS-CoV-2 diffusion (Zoran et al. 2020). As the first evidence showing SARS-CoV-2 harboring on airborne particles, Setti et al. (2020b) found clusters of SARS-CoV-2 RNAs on atmospheric particulate matter in Bergamo, northern Italy, a region burdened with high atmospheric PM levels.

While considerable efforts have been expended on studying the potential implications of airborne particulates in outdoor atmosphere on COVID-19 transmission and symptom aggravation, indoor aerosols-fine particulate matter that is emitted by a common range of sources and human activities-represent an under-investigated route for harboring and transporting airborne pathogens, including SARS-CoV-2. Due to lockdowns, travel restrictions, and other human

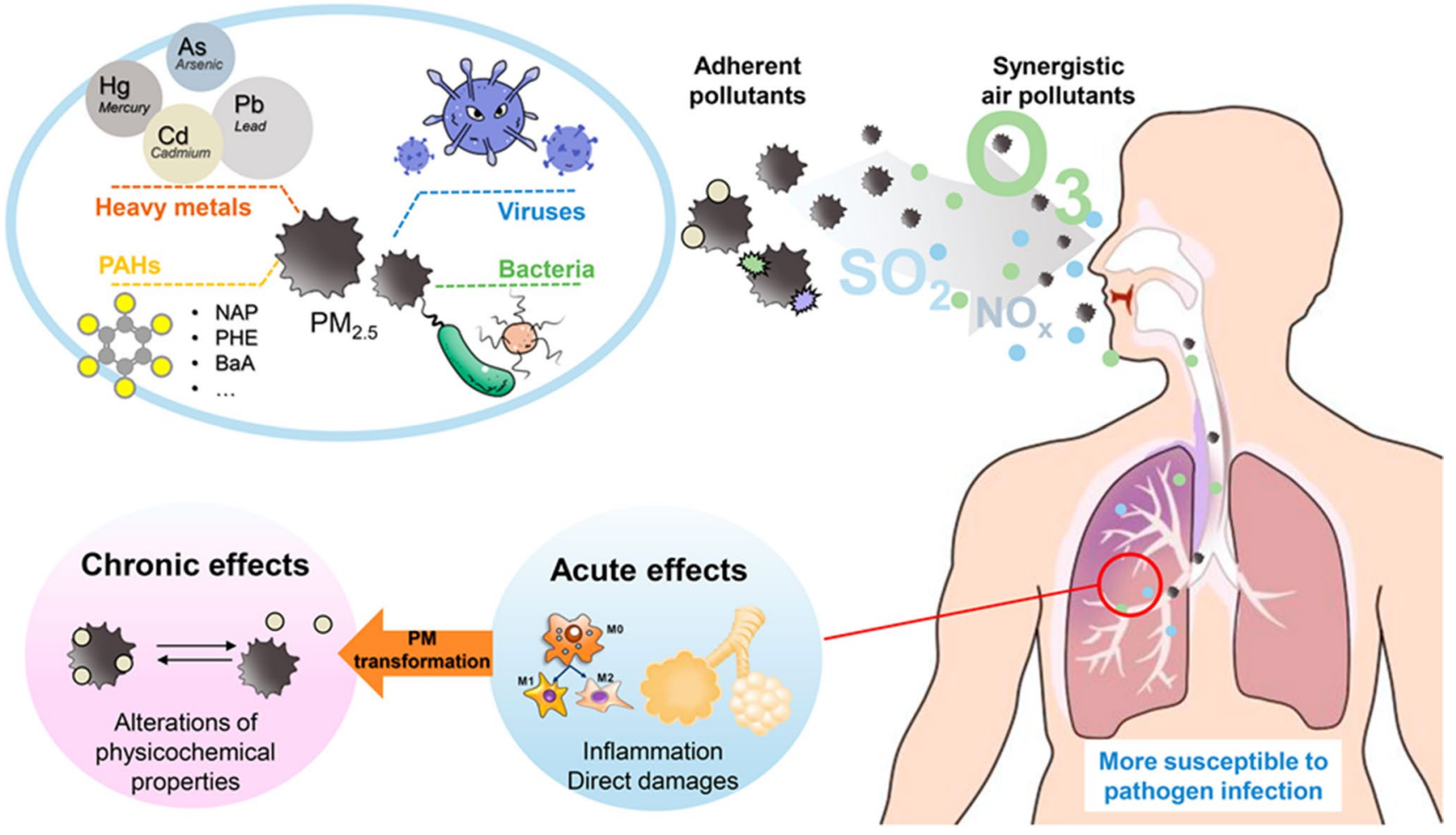

Fig. 1 Health risks of atmospheric particulate matter (PM), and active interplays with entangled pollutants and invading pathogens in the human respiratory system. Reprinted with permission of Elsevier from Ma et al. (2020) 
interventions, outdoor atmospheric particulates underwent significant decreases in many regions during COVID-19, and humans become more impacted by indoor particle emissions in their daily activities (Chauhan and Singh 2020; Li et al. 2017a; Wang et al. 2020; Wu et al. 2018). As a known cause of human respiratory diseases, these fine particulates can present a confounding factor in airborne transmission of COVID-19. An earlier estimate by Morawska et al. (2013) found that about $30 \%$ of human respiratory diseases caused by atmospheric particulates were associated with those generated from indoor sources. A multitude of indoor sources and human activities are known to generate fine particles, or aerosols, in indoor environments, and many of them have unique characteristics in physiochemical properties and aerodynamics in air. Given the fact that most people spend almost $90 \%$ of their time in indoor environments (Klepeis et al. 2001), the role of indoor aerosols in COVID-19 transmission should be scrutinized for effective infection prevention and control, especially in enclosed public settings with high user occupancy or foot traffic which may be high-risk settings for airborne transmission to effectuate. In this article, we aim to present a focused review on the sources and characteristics of common indoor aerosols and based on this information and the recent findings on COVID-19, we discussed their potential implications on COVID-19 transmission. Specifically, evidence and discussions are presented revolving the following topics: i) common sources and characteristics of indoor aerosols, from anthropogenic sources and activities; ii) human respiratory and immune systems impaired by particle inhalation; iii) association between exposure of indoor aerosol particles and the morbidity or mortality of COVID-19; and iv) whether common indoor aerosol particles can act as carriers of SARS-CoV-2.

\section{Sources and characteristics of indoor aerosols}

Understanding the roles and influence of indoor aerosols presents an urgent task in the ongoing scrutiny on the airborne transmission of SARS-CoV-2 in indoor environments, especially in enclosed public spaces where several large clustered outbreaks have been reported (Lewis 2020). To this end, a basic understanding of the sources and characteristics of indoor aerosols, in the context of airborne pathogens, is necessary. In recent discussions, several researchers postulated that particles generated by tobacco smoking and incense burning could facilitate the indoor transmission of SARS-CoV-2 (Amoatey et al. 2020; Mahabee-Gittens et al. 2020). In reality, there are many sources-mostly from human activities - that can generate or resuspend abundant quantities of aerosol particles in indoor air. These include activities involving combustion such as smoking, cooking, candles burning, incense burning, and mosquito coils burning, as well as non-burning sources such as vacuuming, laser printing. As shown in Table 1. large quantities of small particles, typically in the ultrafine range $(<100 \mathrm{~nm})$, can be emitted from common indoor sources, resulting in relatively high mass or particle concentrations in simulated or real indoor environments.

\section{Tobacco smoking}

With about 1 billion smokers around the world, tobacco smoking is one of the most common sources of indoor aerosol emissions. Secondhand smoke poses a major risk factor for indoor occupants, including children, pregnant women, and other non-smokers (Havey et al. 2009; Zhou et al. 2015). Without adequate natural ventilation, smoking can significantly elevate indoor aerosol concentrations in rooms and buildings. Connolly et al. (2009) evaluated indoor air quality in 128 Irish pubs in 15 countries, and found that the average concentration of $\mathrm{PM}_{25}$ in smoking-permitted pubs was $329 \mathrm{\mu g} \mathrm{m}^{-3}$, while that in the smoking-free pubs was equals to $23 \mu \mathrm{g} \mathrm{m}^{-3}$. A similar study was conducted by Hyland et al. (2008), where the authors measured $\mathrm{PM}_{2.5}$ levels in 1822 different workplaces including bars, restaurants, retail outlets, airports in 32 countries. The mean $\mathrm{PM}_{2.5}$ levels in smoking-permitted places were found to be 8.9 times higher than those measured at smoking-free venues. Semple et al. (2015) assessed fine particles levels in 110 Scottish homes. The median $\mathrm{PM}_{2.5}$ concentrations in households with smoking occupants were $31 \mu \mathrm{g} \mathrm{m}^{-3}$ which was approximately ten times greater than those in homes without smokers, suggesting that members of smoking homes were exposed to high concentrations of $\mathrm{PM}_{2.5}$, especially in those lacking ventilation.

Characteristics of aerosols from tobacco smoking have been studied under laboratory settings. By testing five brands of cigarettes, Wu et al. (2012) reported that the mean emission rate of ultrafine particles (UFPs) from smouldering cigarettes was $3.36 \pm 0.24 \times 10^{11}$ particles $\mathrm{min}^{-1}$, which was consistent with the source strength $\left(3.76 \times 10^{11}\right.$ particles $\min ^{-1}$ ) estimated by Afshari et al. (2005). The particle count median diameters of smoking particles were determined to be $102-113 \mathrm{~nm}$. Similar results have also been reported on electronic cigarettes, also known as 'e-cigarettes'. For instance, Fuoco et al. (2014) reported high particle number concentrations $\left(4.39 \pm 0.42 \times 10^{9}\right.$ particles $\left.\mathrm{cm}^{-3}\right)$ in aerosol streams of electronic cigarettes, which were higher than the levels measured on traditional cigarettes under the same conditions. The number distribution mode of electronic cigarettes was in the $120-165 \mathrm{~nm}$ range. Volesky et al. (2018) measured the concentration of $\mathrm{PM}_{2.5}$ and ultrafine particles by testing three different e-cigarettes containing the same nicotine solution in a $\sim 38 \mathrm{~m}^{3}$ office. The authors found that the mean $\mathrm{PM}_{2.5}$ concentration was elevated by 160 - and 103 -fold at $0.5 \mathrm{~m}$ and $1 \mathrm{~m}$ from the smoker, while 


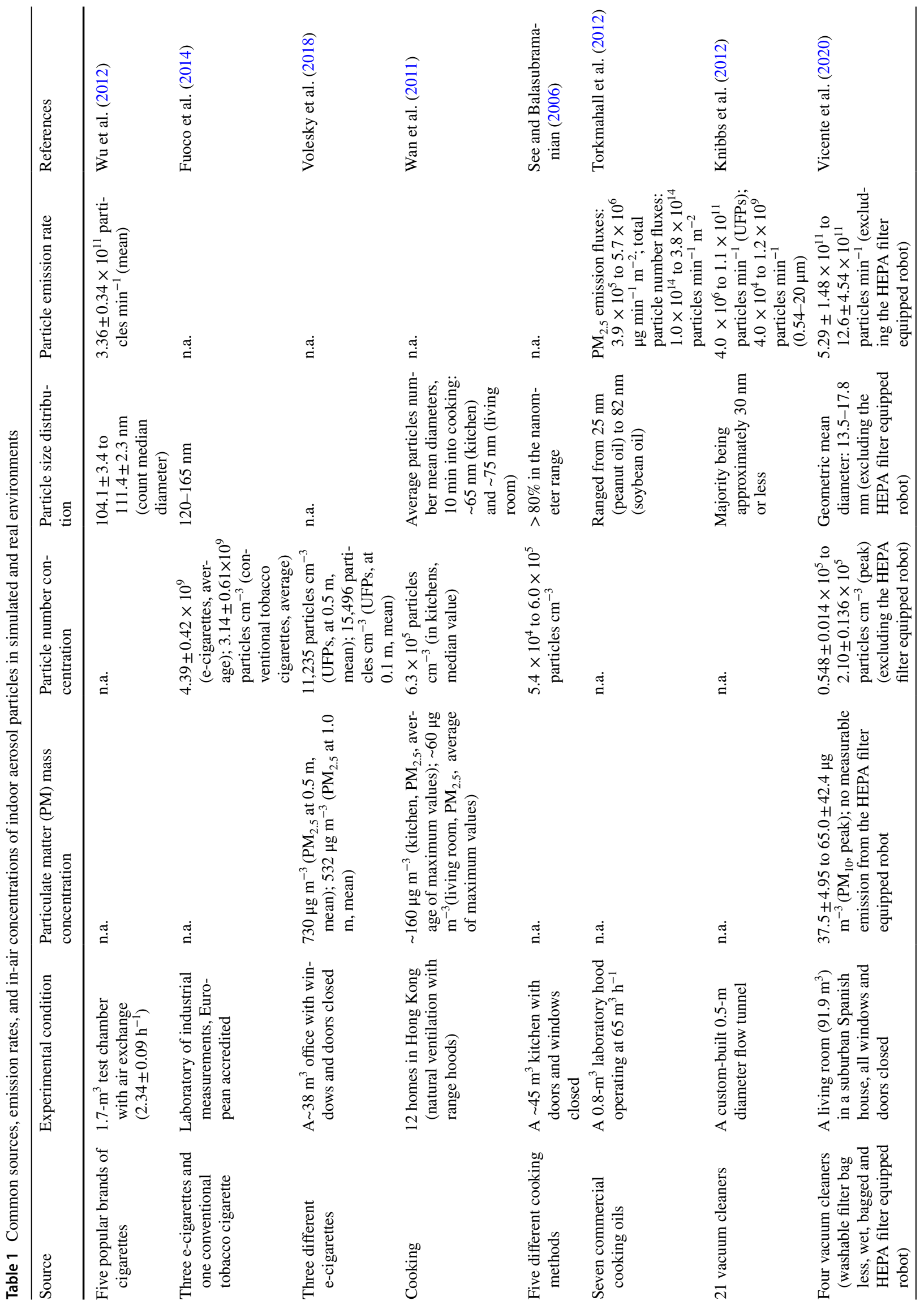




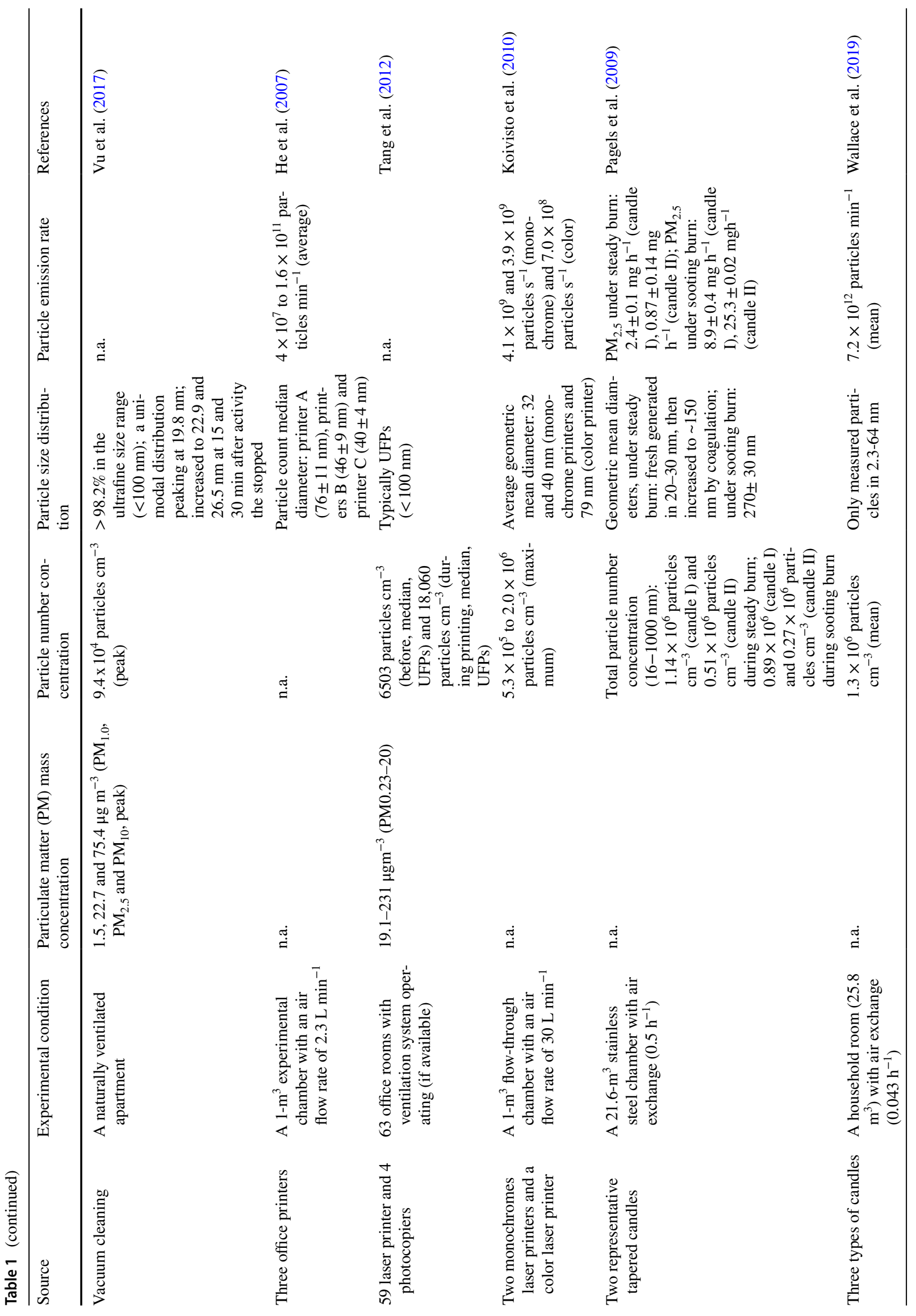




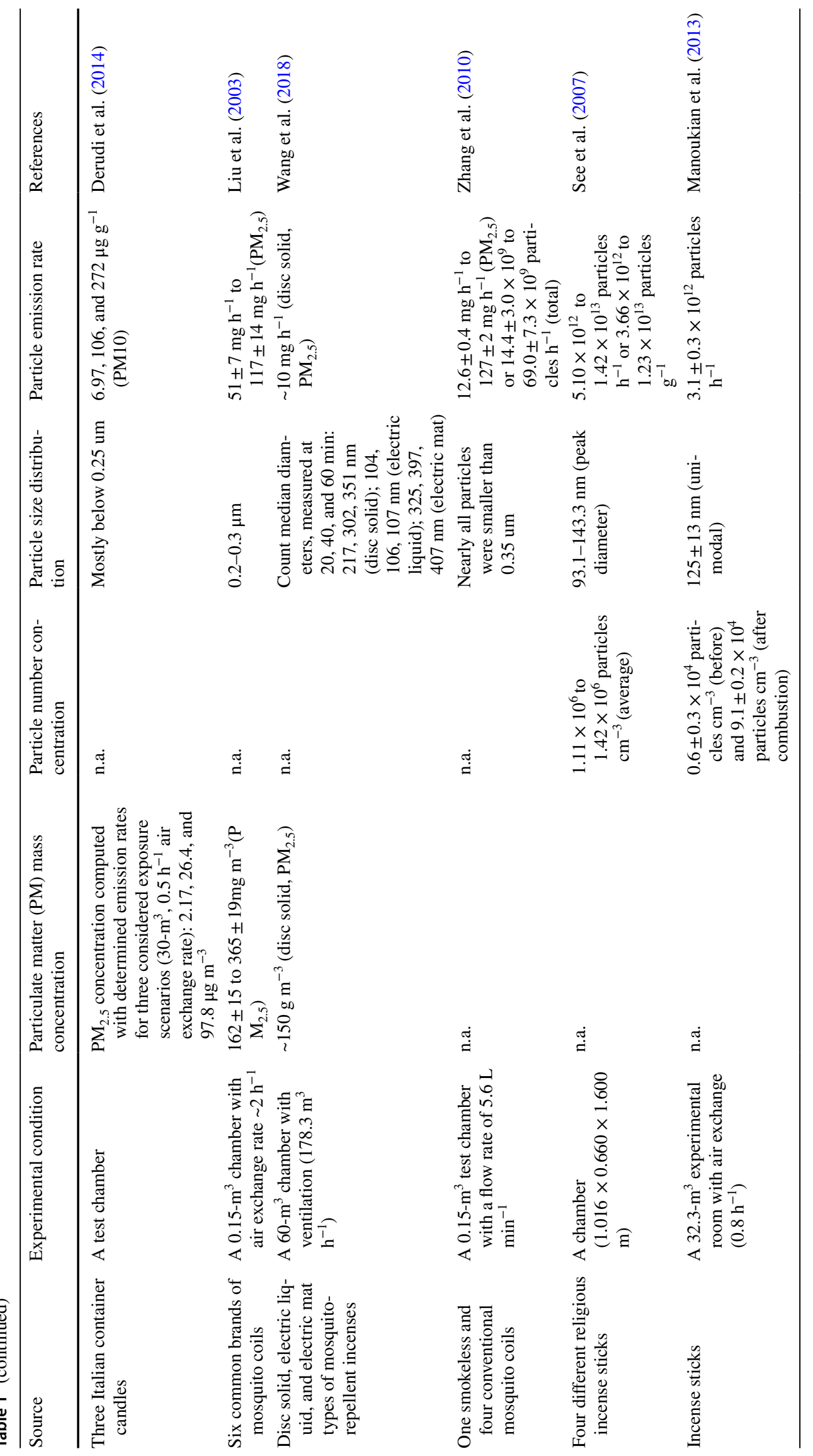


the concentration of ultrafine particles increased by $5.2-$ and 3.0-fold, respectively. The maximum $\mathrm{PM}_{2.5}(174,160 \mu \mathrm{g}$ $\left.\mathrm{m}^{-3}\right)$ and ultrafine particle concentration $(284,260$ particles $\mathrm{cm}^{-3}$ ) were observed at $0.5 \mathrm{~m}$ from the e-cigarette smoker.

\section{Cooking}

In many indoor environments, cooking is recognized as a dominant source of indoor aerosols in terms of both particle count and mass (Vu and Harrison 2019). Wan et al. (2011) measured the $\mathrm{PM}_{2.5}$ levels during and after cooking activities in 12 naturally ventilated, smoking-free homes in Hong Kong. The average $\mathrm{PM}_{2.5}$ concentration increased to $160 \mu \mathrm{g} \mathrm{m}^{-3}$ in the kitchen and airborne particle generated from cooking dispersed quickly and resulted in a $\mathrm{PM}_{2.5}$ concentration of $60 \mu \mathrm{g} \mathrm{m}^{-3}$ in the living room. Meanwhile, particle number concentrations reached $10^{5}$ particles $\mathrm{cm}^{-3}$ both in the kitchen and the living room, with their size distributions mainly in the sub-100 $\mathrm{nm}$ range. Kang et al. (2019) reported that rangehood systems cannot effectively reduce fine particle emissions during cooking activities, while combining rangehood use and natural ventilation reduced cooking particle concentrations, with the average particle decay rate constant increased to $9.1 \mathrm{~h}^{-1}$ from $2.9 \mathrm{~h}^{-1}$ when using the rangehood system alone. Depending on the fuel, cooking oil, food, and cooking method, the characteristics of particles emitted from cooking varied significantly. See and Balasubramanian (2006) investigated particle emissions from five different cooking methods including steaming, boiling, deep-frying, pan-frying, and stir-frying in a domestic kitchen. The study showed that in general cooking with oils generated much more particles than cooking with water. The highest particle number concentration was observed during deep-frying $\left(6.0 \times 10^{5}\right.$ particles $\left.\mathrm{cm}^{-3}\right)$, with a mean particle size of $20 \mathrm{~nm}$. With respect to boiling and steaming, less particles were liberated from the cooking process, although particle number concentrations still exceeded $5.0 \times 10^{4}$ particles $\mathrm{cm}^{-3}$. Torkmahalleh et al. (2012) determined the emission fluxes (i.e., rates per unit area) of seven commercial cooking oils, namely, peanut, coconut, soybean, sunflower, corn, olive, and canola oils. The result showed that cooking with olive oil had the highest $\mathrm{PM}_{2.5}$ emission flux $\left(5.7 \times 10^{6}\right.$ $\mu \mathrm{g} \mathrm{min}{ }^{-1} \mathrm{~m}^{-2}$ ) and the peanut oil had the highest total particle number emission flux $\left(3.8 \times 10^{14}\right.$ particles $\left.\mathrm{min}^{-1} \mathrm{~m}^{-2}\right)$.

\section{Vacuum cleaning}

Vacuum cleaners are commonly used in indoor environments to remove dusts and small debris from floors and surfaces. When operating, vacuum cleaners can also become significant sources of airborne particles for their ability to release or resuspend large amounts of small particles into the indoor air. In a study conducted by Knibbs et al. (2012), authors determined the maximum emission rate of $1.1 \times 10^{11}$ particles $\min ^{-1}$ for ultrafine particles by measuring the emissions from 21 vacuum cleaners, while the minimum emission rate still exceeded $10^{6}$ particles $\mathrm{min}^{-1}$. Regarding larger particles (i.e., sizes in the range of $0.5-20 \mu \mathrm{m}$ ), their emission rates were measured between $4.0 \times 10^{4}$ to $1.2 \times 10^{9}$ particles $\mathrm{min}^{-1}$. The overall $\mathrm{PM}_{2.5}$ emission rates

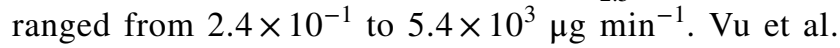
(2017) reported a peak particle number concentration of $9.4 \times 10^{4}$ particles $\mathrm{cm}^{-3}$ in a naturally ventilated apartment during vacuum cleaning, where a unimodal number size distribution was observed with $98 \%$ of particles falling in the ultrafine range with a peak at $19.8 \mathrm{~nm}$. On the particle mass concentration, the peak $\mathrm{PM}_{1.0}, \mathrm{PM}_{2.5}$ and $\mathrm{PM}_{10}$ levels were measured to be $1.5,22.7$ and $75.4 \mu \mathrm{g} \mathrm{m}^{-3}$, respectively. In a recent study, Vicente et al. (2020) investigated the emission rates from four common types of vacuum cleaners, namely, the washable filter bagless, wet, bagged, and HEPA (high-efficiency particulate air) filter equipped robot. Based on their results, the highest $\mathrm{PM}_{10}$ emission rates were observed with the operation of the bagged vacuum cleaner $\left(207 \pm 99.0 \mu \mathrm{g} \mathrm{min}^{-1}\right)$, while similar emission rates were obtained from the wet and washable filter bagless vacuum cleaners $\left(86.1 \pm 16.9 \mu \mathrm{g} \mathrm{min}{ }^{-1}\right.$ and $\left.75.4 \pm 7.9 \mu \mathrm{g} \mathrm{min}^{-1}\right)$. The number emission rates of particles in the size range of 8-322 nm varied from $5.3 \times 10^{11}$ (washable filter bag less vacuum) to $2.1 \times 10^{12}$ (wet vacuum) particles $\mathrm{min}^{-1}$. Notably, operating the HEPA filter equipped vacuum cleaner did not increase the particle mass $\left(\mathrm{PM}_{10}\right)$ or number concentration when compared with the background levels.

\section{Laser printing}

With smoking becoming a prohibited activity in most office buildings, printer emission can be a main source of indoor aerosols in office environments. He et al. (2007) reported an average particle number concentration of $6.5 \pm 8.2 \times 10^{3}$ particle $\mathrm{cm}^{-3}$ during the normal working periods in a $120-\mathrm{m}^{2}$ open-plan office, which was much higher than the equivalent concentration at non-working time $\left(1.2 \pm 0.9 \times 10^{3}\right.$ particles $\mathrm{cm}^{-3}$ ). Tang et al. (2012) assessed the indoor particulate matter level generated by laser printers in 63 German offices. To simulate worst case but realistic conditions commonly encountered in normal office rooms, the authors printed 500 pages in each office with ventilation system operating if available and found substantial releases of ultrafine particles $(<100 \mathrm{~nm})$ during the printing phase. The median particle number concentrations were elevated from $6.5 \times 10^{3}$ particles $\mathrm{cm}^{-3}$ (standby phase) to $1.8 \times 10^{4}$ particles $\mathrm{cm}^{-3}$ (printing phase). The median particle mass concentrations $\left(\mathrm{PM}_{0.23-20}\right)$ were $57 \mu \mathrm{g} \mathrm{m}^{-3}$ and $68 \mu \mathrm{g} \mathrm{m}^{-3}$ in the standby and printing phase, respectively. In the aforementioned study, He et al. (2007) investigated the particle characteristics 
generated by three laser printers in an experimental chamber. Conclusion was drawn that particle emission rates varied greatly with toner coverage and cartridge age, which ranged from $4.0 \times 10^{7}$ to $1.6 \times 10^{11}$ particles $\mathrm{min}^{-1}$. Large numbers of ultrafine particles were emitted by all three types of printers, and the mean particle count median diameter was $76 \pm 11 \mathrm{~nm}, 46 \pm 9 \mathrm{~nm}$, and $40 \pm 4 \mathrm{~nm}$, respectively. Koivisto et al. (2010) compared the particle emissions of two monochromes laser printers and a color laser printer in a flow-through chamber. The emission rates were measured to be $4.1 \times 10^{9}$ and $3.9 \times 10^{9}$ particles s$^{-1}$ for the monochrome printers and $7.0 \times 10^{8}$ particles $\mathrm{s}^{-1}$ for the color printer. The geometric mean diameter of emission particles was larger for the color laser printer $(79 \mathrm{~nm})$ compared with the two monochrome laser printers (32 and $40 \mathrm{~nm}$ ).

\section{Candle burning}

An overlooked source in recent studies and discussions (Kumar et al. 2013; Li et al. 2017c; Manigrasso et al. 2018), candle burning can be a substantial source of indoor particle emissions (Rogula-Kopiec et al. 2019). In the modern society, candles are no longer used primarily for lighting, but for esthetic and religious purposes such as meditation, memorials, and ceremonies, usually in indoor settings. Studies have shown that large quantities of fine particles are emitted during candle burning, mostly in the micron to submicron range. Afshari et al. (2005) characterized 13 different indoor particle sources in a $32-\mathrm{m}^{3}$ chamber with a constant air exchange rate of $1.7 \pm 0.1 \mathrm{~h}^{-1}$ with outside air. The study found that burning pure wax candles generated the highest concentration of ultrafine particles $\left(2.4 \times 10^{5}\right.$ particles $\mathrm{cm}^{-3}$ ) than smoking, frying meat, cooking with an electric stove, and all other sources of particle emission. Pagels et al. (2009) tested two representative tapered candles in a 21.6- $\mathrm{m}^{3}$ stainless steel chamber with an air exchange rate of $0.5 \mathrm{~h}^{-1}$. The authors found that the geometric mean diameter of the generated particles peaked at 20-30 nm during the steady-burn period, and at $270 \pm 30 \mathrm{~nm}$ during the sooting-burn period. In a recent study, Wallace et al. (2019) measured the indoor ultrafine particles (2.3-64 nm) originated from burning candles in a residence. During the steady-burn stage, the mean emission rates of ultrafine particles were up to $7.2 \times 10^{12}$ particles $\min ^{-1}$, while the total particles number emission rate reached $10^{13}$ particles min $^{-1}$ in the room. Particle emissions from candles varied greatly with different products. Derudi et al. (2014) reported that the total $\mathrm{PM}_{\mathrm{x}}$ emission was measured to be 7.0, 106, $272 \mu \mathrm{g} \mathrm{g}^{-1}$ for three Italian container candles constituted by different paraffin waxes. The authors further determined the air quality for the considered exposure scenario of a $30-\mathrm{m}^{3}$ room with an air exchange rate of $0.5 \mathrm{~h}^{-1}$. With two candles of the same type burning simultaneously, the steady-state $\mathrm{PM}_{2.5}$ concentration was estimated to be $2.17,26.4$, and $97.8 \mu \mathrm{g}$ $\mathrm{m}^{-3}$ in the well-mixed room environment, respectively.

\section{Mosquito coil burning}

Mosquito coils are widely used in Africa, Asia, and South America as an insect repellant in summer (Zhang et al. 2010). To achieve the desired effects, mosquito coils are often used in enclosed spaces and burned slowly through the night. Their typical patterns of use mean that users may be continuously exposed to high concentrations of indoor particulate matter for several hours in non-ventilated indoor environments. Liu et al. (2003) investigated several types of commonly used mosquito coils in China and Malaysia. The burning periods of those products ranged from $7 \mathrm{~h}$ to $11 \mathrm{~h}$, and $\mathrm{PM}_{2.5}$ emission rates varied considerably for different mosquito coils between $51 \pm 7 \mathrm{mg} \mathrm{h}^{-1}$ and $117 \pm 14 \mathrm{mg} \mathrm{h}^{-1}$. The size distribution of mosquito coil combustion particles generally fell in the sub-micron range, mostly below $0.3 \mu \mathrm{m}$. Salvi et al. (2016) tested three types of mosquito coils in India in a room $(5.7 \mathrm{~m} \times 3 \mathrm{~m} \times 2.4 \mathrm{~m})$ with the doors and windows closed, and found that all of the three products emitted massive amounts of particles with a mean $\mathrm{PM}_{2.5}$ concentration of $1031 \mu \mathrm{g} \mathrm{m}^{-3}$. Wang et al. (2018) characterized the emissions from disc solid, electric liquid, and electric mat types of mosquito-repellent incenses in a large $60-\mathrm{m}^{3}$ chamber under a ventilation rate of $3.0 \mathrm{~m}^{3} \mathrm{~min}^{-1}$. The highest $\mathrm{PM}_{2.5}$ emission rate was found on the disc solid type, which was 10-fold greater than the electric liquid type and five-fold higher than the electric mat type. Notably, Zhang et al. (2010) assessed the particle emissions from a 'smokeless' mosquito coil and compared them with four conventional mosquito coils. The results showed that the smokeless mosquito coil had lower emission rates in terms of both the mass of $\mathrm{PM}_{2.5}\left(12.6 \pm 0.4 \mathrm{mg} \mathrm{h}^{-1}\right)$ and the total number of particles $\left(14.4 \pm 3.0 \times 10^{9}\right.$ particles $\left.\mathrm{h}^{-1}\right)$. With respect to conventional mosquito coils, the $\mathrm{PM}_{2.5}$ and total particle number emission rates were in the range of $62.8 \pm 1.8$ to $127 \pm 2 \mathrm{mg}$ $\mathrm{h}^{-1}$ and $(43.4 \pm 4.1) \times 10^{9}$ to $(69.0 \pm 7.3) \times 10^{9}$ particles $^{-1}$, respectively. The study also found that nearly all particles originated from burning mosquito coils were smaller than $0.35 \mu \mathrm{m}$.

\section{Incense burning}

From the far East to the West, incenses are commonly used in temples, churches, and in devotees' residence (See et al. 2007; Yang et al. 2013). In the Arabian Peninsula, they are also used for improving scents or removing odors in homes (Cohen et al. 2013). As a visible source of particle emissions, burning incenses indoor often leads to substantial increases in particle concentrations in air (Hsueh et al. 2011). Weber (2006) reported that the $\mathrm{PM}_{10}$ and $\mathrm{PM}_{1.0}$ levels underwent a 
6.9- and 9.1-time increase during incense burning in a German catholic church. Goel et al. (2017) reported high $\mathrm{PM}_{10}$ mass concentrations in an Indian temple with measurements up to $2184 \mu \mathrm{g} \mathrm{m}^{-3}$, where $99 \%$ of the released particles were $\mathrm{PM}_{2.5}$. Manoukian et al. (2013) reported that burning $0.5 \mathrm{~g}$ incense in $30 \mathrm{~min}$ could increase the number of ambient particles by 15 times from the background level in a 32.3$\mathrm{m}^{3}$ rectangular-shaped chamber with an air exchange rate of $0.8 \mathrm{~h}^{-1}$. The particle concentration in air increased from $0.6 \pm 0.3 \times 10^{4}$ particles $\mathrm{cm}^{-3}$ to $9.1 \pm 0.2 \times 10^{4}$ particles $\mathrm{cm}^{-3}$, with an emission rate of $3.1 \pm 0.3 \times 10^{12}$ particles $\mathrm{h}^{-1}$ during this period and a unimodal size distribution centering at $125 \pm 13 \mathrm{~nm}$. Wang et al. (2006) characterized the particles released from incense burning in an $18-\mathrm{m}^{3}$ stainless steel chamber with an air exchange rate of $0.5 \mathrm{~h}^{-1}$. The results showed that burning church incense generated the highest $\mathrm{PM}_{2.5}$ concentrations (up to $6025 \mu \mathrm{g} \mathrm{m}^{-3}$ ), while burning the traditional and aromatic incenses generated an average $\mathrm{PM}_{2.5}$ concentration of 1391 and $502 \mu \mathrm{g} \mathrm{m}^{-3}$, respectively. See et al. (2007) tested four different religious incense sticks used in eastern countries by Hindus, Buddhists, Taoists, and Shinto followers. The authors identified large numbers of fine particles emitted during incense burning with a magnitude of $10^{12}-10^{13}$ particles $\mathrm{g}^{-1}$ and a particle size distribution peaked around $100 \mathrm{~nm}$.

\section{Implications of indoor aerosols on the COVID-19 pandemic}

\section{Human respiratory and immune systems impaired by particle inhalation}

An early national survey in the United States showed that in general, people spent nearly $90 \%$ of their time in various indoor environments (Klepeis et al. 2001). The trend was reinforced in recent surveys that people increasingly adopted sedentary lifestyles by spending more time indoor (Gong et al. 2019; Yang et al. 2019). Since there are many common indoor sources that can emit substantial quantities of fine and ultrafine particles, which can remain suspended and accumulate in air, the wide adoption of sedentary lifestyles in the general population increases their likelihood of exposure to indoor aerosols, especially in enclosed spaces with inadequate ventilation.

The WHO estimated that as many as seven million people die each year due to exposure to fine particulate matter and associated diseases such as asthma, stroke, cardiovascular diseases, lung cancer, chronic obstructive pulmonary diseases, and respiratory infections, including pneumonia (WHO 2018). The mechanisms of airborne particle-induced adverse health effects are believed to mainly involve oxidative stress and inflammation. Oxidative stress mediated by airborne particles can be due to direct generation of reactive oxygen species (ROS) from the surface of particles containing metals, polycyclic aromatic hydrocarbons (PAHs), and so on. Meanwhile, mitochondria, cell membranes, phagosomes, and the endoplasmic reticulum also produce ROS after exposure to particulate matter. Studies showed that ROS could impair the structure and function of bio-macromolecules, including lipids, proteins, and DNAs (Feng et al. 2016; Moller et al. 2010). Excessive ROS may activate signaling pathways and further lead to cell apoptosis or necrosis (Azad et al. 2009). With respect to inflammation, the alveolar macrophages and airway/bronchial epithelial cells are the primary venues to process inhaled airborne particles, and both types of cells produce proinflammatory mediators upon exposure to particulate matter (Fujii et al. 2001; Miyata and van Eeden 2011). Moreover, alveolar macrophages and epithelial cells could interact, resulting in a synergistic increase in the production and secretion of proinflammatory mediators including GM-CSF and IL-6 (Fujii et al. 2002). The two cytokines can magnify local inflammatory responses or even lead to a systemic inflammatory response. Further, exposure to atmospheric particulates can also result in pathology changes in lung and respiratory tract, such as increased cell permeability, inflammatory cell infiltration, bronchial mucosal injury, and alveolar collapse (Liu et al. 2017a; Riva et al. 2011; Wang et al. 2015). To summarize, exposure to those indoor generated ultrafine particles could impair human respiratory tracts via oxidative stress and inflammatory response.

Exposure to respirable particles also impairs the host defense of the human respiratory system, which can lead to increased susceptibility to pathogen infections (Fig. 1). First, inhaled particles can impair the nasal and bronchial mucociliary system and result in low bacterial clearance, which often serves as the first line of host defense (Duan et al. 2013; Jia et al. 2019). Also, the tight junction of airway epithelial barrier can be impaired by oxidative stress, yielding increased permeability which allows invading pathogens to more easily pass through (Liu et al. 2019). Secondly, particle exposure can induce apoptosis and autophagy of lung epithelial cells and alveolar macrophages, and both play important roles in processing inhaled particles (Deng et al. 2013; Deng et al. 2014; Huang et al. 2004). In addition, studies showed that the dysfunctions of cytoskeletal in alveolar macrophages, impaired response of natural killer cells, and disrupted physical and immunological functions of pulmonary surfactants caused by particle exposure all hampered phagocytic defense reaction (Chen et al. 2016; Moeller et al. 2005). Last but not least, particle exposure changes the normal bacterial flora in the respiratory tract, which is an important part of the natural immune defense and prevents the invasion of pathogens or foreign substances through a variety of mechanisms (Yang et al. 2020). Overall, 
inhaling indoor aerosol particles could further damage the host defense and facilitate the intrusion of pathogens.

\section{Increased COVID-19 morbidity and mortality due to exposure to indoor aerosol particles}

Epidemiological studies on outpatient visits, respiratory emergency department visits and hospital admissions manifested a positive association between particle exposure and human respiratory infections (Li et al. 2017b; Strosnider et al. 2019; Xia et al. 2017). Similar conclusions were drawn from related animal models that exposure to particulate matter increased susceptibility to pulmonary infections (Liu et al. 2019; Zhao et al. 2014). It is worth noting that although positive correlations have been observed between outdoor atmospheric particulate matter and COVID-19 morbidity, knowledge on indoor aerosol particles and their implications on the susceptibility of COVID-19 infection and symptom aggravation in patients is limited in current literature. Depending on their sources of emission, indoor aerosol particles may have unique characteristics in terms of their chemical composition, size distribution, electrostatic charges, and aerodynamics, which not only affect their transport in air but their deposition and effects in human airways. Moreover, most indoor emission sources are in close proximity to human occupants in a confined environment, meaning that fresh and active particles may be inhaled by human shortly after their release, as opposed to the homogenous mixture of aged particles present in the open outdoor atmosphere.

As discussed earlier, particle emissions from common indoor sources may contain significant quantities of fine particulates, most of which fall in the sub- $100 \mathrm{~nm}$ range (i.e., ultrafine particles) (Table 1). Compared with larger atmospheric particles, such as the $\mathrm{PM}_{10}$ and $\mathrm{PM}_{2.5}$, ultrafine particles not only can persist in air for longer periods (Fig. 2) but deposit in the deeper regions of the human airways (Fig. 3). Specifically, ultrafine particles with sizes around $20 \mathrm{~nm}$ showed the highest deposition rate in the alveolar region (up to 50\%), which is consistent with the sizes of most particles released during candle burning (Pagels et al. 2009). Chen et al. (2016) predicted the fractional depositions of inhaled particles in the human respiratory tract during nose breathing (Fig. 3). Based on the results, most ultrafine particles generated from common indoor emission sources have the highest deposition efficiency in the deeper alveolar region rather than the tracheobronchial and nasopharyngeal regions. In a more recent study, Manigrasso et al. (2018) estimated that the total particle number doses emitted from common indoor sources were deposited in the head (15-17\%), tracheobronchial (30-32\%) and alveolar (51-56\%) regions, with peak number doses reaching up to $10^{10}$ particles after a single respiratory act. The study suggested that large quantities

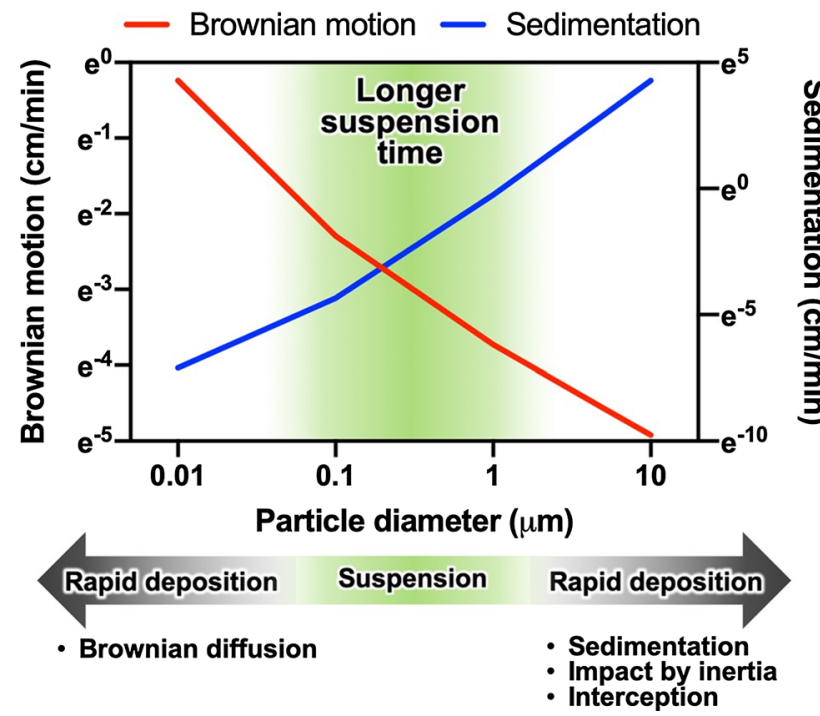

Fig. 2 Deposition behaviors of airborne particles in various size ranges. Ultrafine particles $(<100 \mathrm{~nm})$ are rapidly deposited by Brownian diffusion, especially those smaller than $20 \mathrm{~nm}$. Large coarse particles are deposited by sedimentation, impact by inertia, and interception. Particles between $30 \mathrm{~nm}$ and $1.0 \mu \mathrm{m}$ tend to have longer atmospheric lifetimes because they are less likely to be deposited in either way. These particles can also accumulate in air due to their long suspension time. Reprinted with permission of Springer Nature from Kwon et al. (2020)

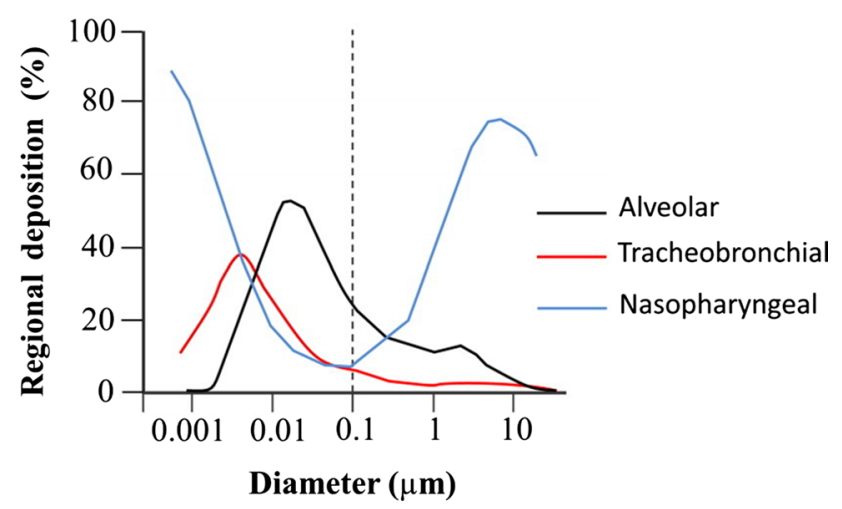

Fig. 3 Predicted fractional depositions of inhaled particles in the human respiratory tract during nose breathing, based on data from the International Commission on Radiological Protection (ICRP 1994). Reprinted with permission of Elsevier from Chen et al. (2016)

of ultrafine particles can directly induce toxicity effects in the lung and even across the alveolar epithelium into the blood vessel.

It is difficult for the human respiratory system to clear ultrafine particles inhaled into deeper regions. Even after $24 \mathrm{~h}$ of inhalation, most ultrafine particles could remain deposited in the lung periphery and conducting airways (Moller et al. 2008). Compared with larger particles, these ultrafine particles usually have orders of magnitude higher 
surface areas absorbing air pollutants (oxidants, organic compounds, metals), which can induce more oxidative stress and inflammation and further impair the host defense system, causing higher morbidity and mortality in respiratory infections. With respect to COVID-19, exposure to airborne particles could elevate the expression of angiotensin-converting enzyme 2 (ACE2), the receptor of SARS-CoV-2 and responsible for its host cell entry (Hoffmann et al. 2020; Lin et al. 2018). Recent studies demonstrated that exposure to cigarette smoke particles upregulated the expression of ACE2 and increased the susceptibility of the host to COVID19 infection (Brake et al. 2020; Smith et al. 2020).

Indoor aerosol exposure can also aggravate the symptoms of infection in COVID-19 patients. Mishra et al. (2020) reported that exposure to particulate matter could promote the replication of RNA viruses by suppressing the antiviral innate immune response. Zhou et al. (2020) conducted a comprehensive analysis of 30 immunological indicators in the blood of COVID-19 patients $(n=33)$ and elucidated the key mechanism of severe pneumonia cytokine storm caused by SARS-CoV-2. The study showed that after SARS-CoV-2 infection, $\mathrm{CD}^{+}{ }^{+} \mathrm{T}$ lymphocytes were quickly activated to become pathogenic Thelper (Th) 1 cells and produced GMCSF. The cytokine environment induced $\mathrm{CD} 14^{+} \mathrm{CD} 16^{+}$ inflammatory monocytes with a high expression of IL-6 and other inflammatory mediators, forming an inflammatory cytokine storm and causing severe immune damage to the lungs and other organs or even quick mortality. These echoed with findings in an earlier study where researchers found that exposure to particles increased the production of inflammatory cytokines including GM-CSF and IL-6 (Fujii et al. 2002). These findings provided mechanistic insights into the positive correlation between particle exposure and symptom aggravation of respiratory pathogen infection, which may explain the consistent trend of high fatality rates observed in COVID-19 patients in regions with air pollution (Paital and Agrawal 2020; Roviello and Roviello 2020; Wang et al. 2020; Wu et al. 2020; Yao et al. 2020). In summary, ultrafine particles released from common sources could deposit in the deeper lung region upon inhaling. Impaired host defense, upregulation of ACE2, and aggravated cytokine storm subsequently caused by these particles would increase the likelihood of COVID-19 infection and fatality.

\section{Can indoor aerosol particles become effective airborne carriers of SARS-CoV-2?}

Evidence on viruses, bacteria, and fungi recovered from atmospheric particles suggested that those could act as airborne carriers of human pathogens (Gast et al. 2004; Ryan et al. 2009; Yan et al. 2019; Zucker et al. 2000). Alonso et al. (2014) reported that porcine epidemic diarrhea virus (i.e., a Coronaviridae family member) harbored by airborne particles remained infectious after being transported over long distances, where genetic materials of the virus were detected in the downwind of infected swine farms at a distance of ten miles. Zhao et al. (2019) also reported that avian influenza viruses from infected poultry farms could spread across different states while being carried by fine particulate matter in air. Recently, researchers have postulated that atmospheric particulate matter may play an important role in SARS-CoV-2 transmission. In an early viewpoint, Qu et al. (2020) hypothesized that SARS-CoV-2 can adsorb onto air dusts or particulates and facilitate its long-distance transmission. Similar opinion was proposed by Prather et al. (2020) that viruses can attach to airborne dusts or other air pollutants which can facilitate their dissemination via increased dispersion and modified aerodynamic characteristics. Setti et al. (2020a) further proposed that SARS-CoV-2 may create clusters with atmospheric particles and subsequently enhance the dispersion and accumulation of the virus in air. Direct evidence on the presence of SARS-CoV-2 on airborne particles was reported by Setti et al. (2020b). The authors first detected the genetic materials of SARS-CoV-2 in atmospheric particulates in northern Italy, a region burdened with elevated levels of particulate matter in air and high mortality rates of COVID-19. Based on these findings, the authors suggested that SARS-CoV-2 could form clusters with $\mathrm{PM}_{10}$ present in the outdoor atmosphere.

Bioaerosols containing respiratory pathogens can be generated from the exhaling, talking, coughing, and sneezing of infected individuals, posing risks to co-occupants in enclosed indoor environments (Morawska and Milton 2020). $\mathrm{Xu}$ et al. (2017) reported a $107 \%$ increase in bioaerosol concentration in a $27-\mathrm{m}^{3}$ enclosed experimental room after a 30-min presence of five adults without wearing face coverings. The average emission rate was determined to be $8.4 \times$ $10^{5}$ particles person ${ }^{-1} \mathrm{~h}^{-1}$ in the 'no-mask' scenario. When medical masks or $\mathrm{N} 95$ respirators were worn by the five occupants, bioaerosol increases were reduced to $31-81 \%$ under the same conditions. Buonanno et al. (2020) estimated the quantum emission rates of SARS-CoV-2 infected subjects, where a 'quantum' was defined as the dose of airborne droplet nuclei required to cause infection in $63 \%$ of susceptible individuals. The study estimated that the expiratory viral load of a virus-infected person when speaking and breathing were 320 and 10.5 quanta $\mathrm{h}^{-1}$, respectively. Droplets and droplet nuclei generated from human respiratory activities may also associate with airborne particles, including aerosol particles commonly found in indoor air. Some researchers recently postulated that aerosol particles originated from some indoor sources could become carriers for SARSCoV-2. Mahabee-Gittens et al. (2020) underscored the possibility of SARS-CoV-2 virions (average diameter $100 \mathrm{~nm}$ ) attaching to smoking particles with diameters of $0.2-0.5 \mu \mathrm{m}$ emitted from e-cigarettes and combustible tobaccos, which 
may enhance the transmission of the novel coronavirus in smoking environments. Amoatey et al. (2020) highlighted the risk that airborne particles emitted from indoor incense burning may carry SARS-CoV-2 virus and promote the dissemination of COVID-19 in Middle East homes. However, no experimental data or evidence were supplied in those discussions to validate the hypotheses. Given the ubiquitous presence of indoor aerosol particles and the elevated risks of transmitting respiratory pathogens in enclosed environments, an effective transmission route mediated by those invisible agents-once we achieve a better understanding on their roles-would require urgent assessment and public attention in the ongoing pandemic with worsening situations and re-emergent outbreaks reported in countries and regions (Han et al. 2020; Sun and Han 2020; WHO 2020c).

Can indoor aerosol particles become effective carriers of SARS-CoV-2? There are a few important things to consider before we can answer this question. First, particles emitted from common indoor emission sources typically fell in the sub-micron range, where a large part of them are ultrafine $(<100 \mathrm{~nm})$ particles (Table 1). It is important to note that these particles are of comparable size or even smaller than the virion of the novel coronavirus $(60-140 \mathrm{~nm})$. While they may associate with other particles when suspended in air, it may be difficult for these tiny particles to become carrying substrates of the viruses. Adding to this argument, SARS$\mathrm{CoV}-2$ viruses rarely enter the air as single, isolated virions. Like other respiratory pathogens, they are contained in various sizes of electrolyte-containing droplets when expelled from mouth and nose. Most of the small-sized human respiratory droplets (e.g., $<10 \mu \mathrm{m}$ ) would quickly evaporate into droplet nuclei, typically in less than $1.5 \mathrm{~s}$, and the vast majority of droplets generated by human respiratory activities fall into this particular size range (Wei and $\mathrm{Li}$ 2015). Xu et al. (2017) reported that bioaerosols released from human breathing peaked at $1.5 \mu \mathrm{m}$, which was consistent with the results reported by Morawska et al. (2009). In the latter study, authors showed the bimodal distributions of droplets released from human breathing, speech, and mild coughing, with two prominent peaks shown at $1.8 \mu \mathrm{m}$ and below $0.8 \mu \mathrm{m}$ (Morawska et al. 2009). Droplets generated from human sneezing are often much larger in size. Han et al. (2013) found that the size distribution of sneeze droplets resembled a lognormal profile with a geometric mean size of $360 \mu \mathrm{m}$ (unimodal distribution) and $74.4 \mu \mathrm{m}$ (bimodal distribution). The components of human respiratory droplets are complicated. Apart from water and microorganisms, they contain electrolytes, sugars, enzymes, cells and remnants (Stadnytskyi et al. 2020). With the exception of large droplets which would quickly settle on the floor while evaporating (e.g., large sneezing droplets), most human respiratory droplets evaporate quickly to equilibrium sizeswhich would depend on the humidity of the ambient air, initial droplet sizes and contents of droplets-or become droplet nuclei and stay airborne. It was estimated that the sizes of those droplet nuclei were typically about half of those of the original droplets (Liu et al. 2017b; Nicas et al. 2005). Meanwhile, limited studies pointed out that particles released from some indoor emission sources would undergo a coagulation process, reaching larger particle sizes although they still remained in the sub-micron range (Table 1). In those cases, the virus-laden droplet nuclei would still be significantly larger than those coagulated aerosol particles.

Given the fact that both the virus-laden droplet nuclei and indoor aerosol particles can suspend and accumulate in air for long periods of time (Fig. 2), they may form 'clusters' or 'aggregates' and subsequently alter the aerodynamic characteristics of their parent particles, causing either longer suspension or faster settlement via inertial impaction, electrostatic attraction, or repulsion (He and Han 2020; Yu 2014). Such coalescence clusters may protect the virus inside from radiation or toxic chemicals (Zuo et al. 2013). Setti et al. (2020a) pointed out that coalescence of droplet nuclei and aerosol particles is more likely to occur in environments with high relative humidity. In a set of experiments assessing bioaerosol emissions from human exhaled breath, $\mathrm{Xu}$ et al. (2017) consistently observed abnormal reductions in total particulate matter number concentrations during the increases in bioaerosol particles in air. Although no interpretation was offered in the study, a plausible explanation for this phenomenon is that bioaerosols generated from human activities formed aggregates with indoor particulate matter and reduced the total number of particulates suspended in air. It is unclear whether those coalescent particles settled on surfaces or objects, or remained suspended in air after getting better aerodynamic characteristics. Further evidence was found in aerosol sampling in commercial airplanes, health centers, and daycare centers during flu seasons, where large numbers of genome copies of influenza A virus (similar to SARS-CoV-2 in size) were detected in their indoor air (Fig. 4). Of these, $64 \%$ of viral genome copies were detected on airborne particles smaller than $2.5 \mu \mathrm{m}$, a size range allowing long periods of particle buoyancy in air (Yang et al. 2011). Unfortunately, in this study authors did not analyze the sources and characteristics of those virusladen particles, and thus no conclusion could be drawn on whether the detected viruses in air were from virus-laden droplet nuclei or coalescent clusters formed by indoor aerosols, droplet nuclei, or both. In other words, while virusladen droplets and droplet nuclei can interact with indoor aerosol particles, whether these interactions would facilitate the airborne transmission or the settlement of the virus and how they would affect the viability of the virus in common indoor environments are largely unknown. In the midst of a prolonging pandemic, these present some urgent questions for scientists and public health authorities on the airborne 
(a) 10 Dec 2009 health centre

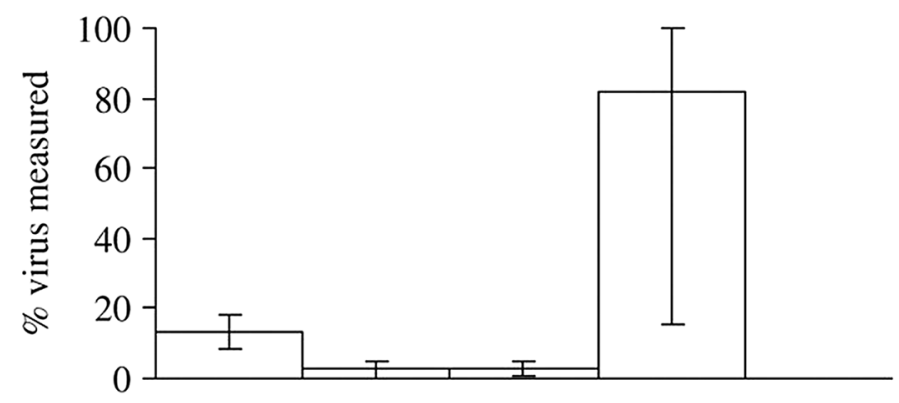

(c) 27 Jan 2010 day-care centre

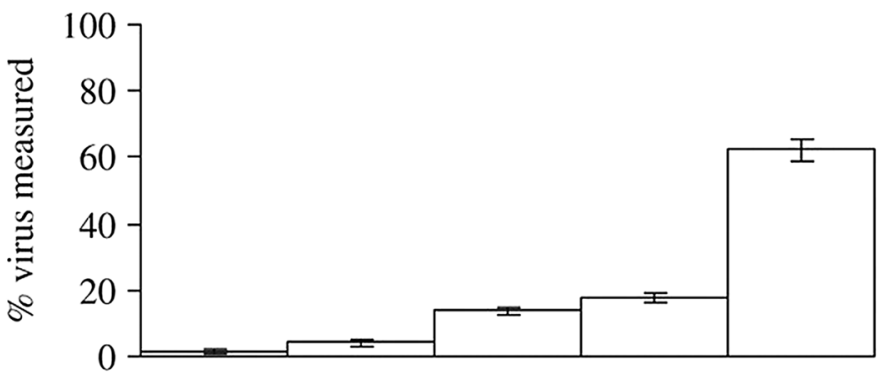

(e) 22 Mar 2010 aeroplane

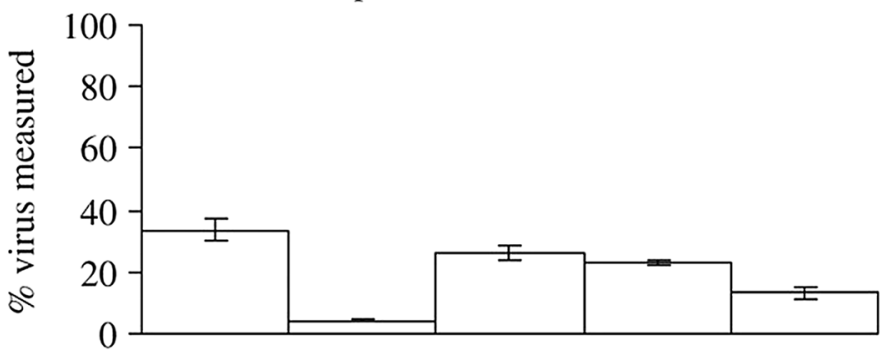

(g) 31 Mar 2010 day-care centre

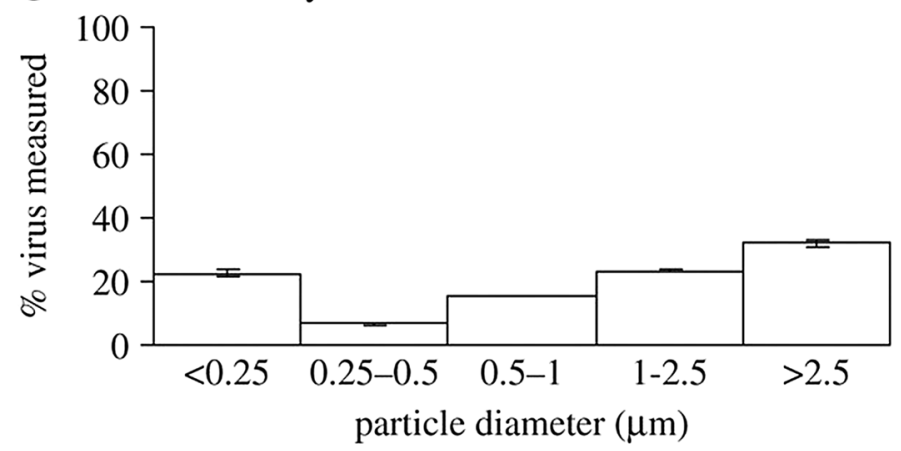

(b) 17 Dec 2009 day-care centre

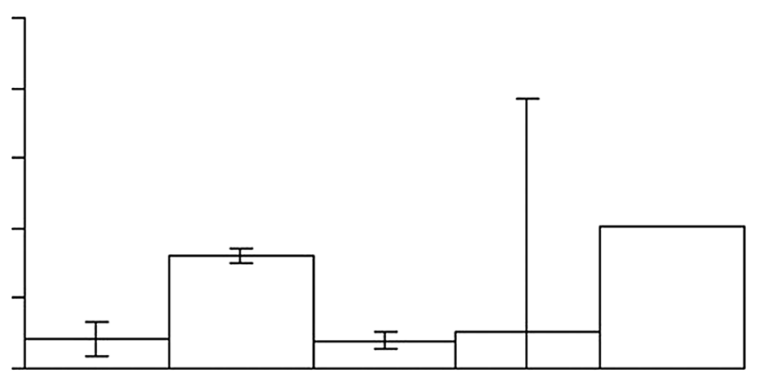

(d) 9 Feb 2010 health centre

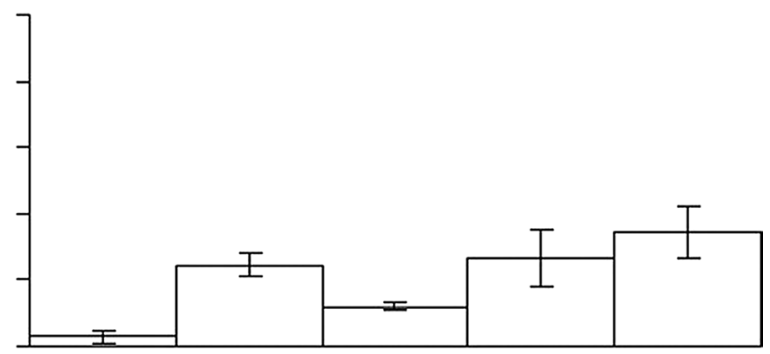

(f) 24 Mar 2010 aeroplane

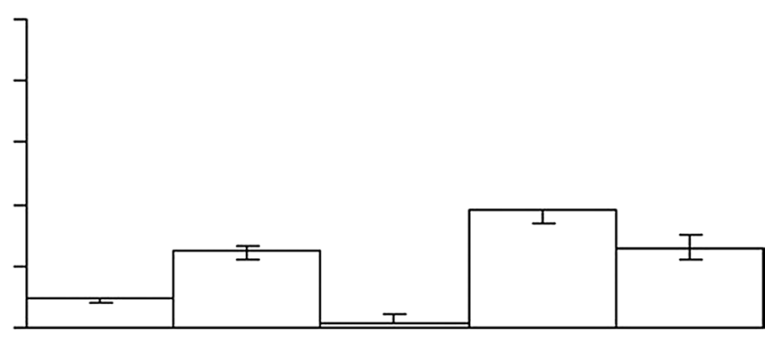

(h) 6 Apr 2010 health centre

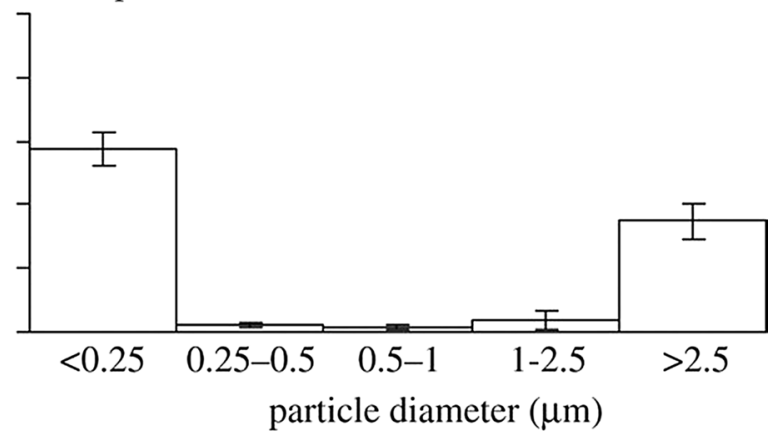

Fig. 4 Particle size distributions in each positive sample containing airborne influenza A viruses (sample date and location shown on top). Aerosol samples were collected over a $6-8 \mathrm{~h}$ period in each location using a cascade impactor with cut-point diameters of 0.25 , $0.5,1.0$ and $2.5 \mu \mathrm{m}$. The $y$-axis indicates the percentage of total virus genome copies found in each size range. In seven of the eight cases, the majority of viruses were associated with fine atmospheric particles smaller than $2.5 \mu \mathrm{m}$. Reprinted with permission of Royal Society from Yang et al. (2011)

\section{Conclusion}

Exposure to indoor aerosol particles constitutes a potential 
risk factor for the general population in the current pandemic. Billions or even trillions of ultrafine particles, below $0.1 \mu \mathrm{m}$, are emitted per minute by a variety of indoor sources, e.g., smoking, cooking, vacuum cleaning, laser printing, candle burning, mosquito coil burning, and incense burning, and remain buoyant in indoor air. The peak dose of particle disposition can reach up to $10^{10}$ particles in the human respiratory system after a single respiratory act in indoor environments with common sources of aerosol particle emissions. Inhaled small aerosol particles can induce oxidative stress and inflammation, causing adverse respiratory symptomology and increasing the likelihood of pulmonary infection. Importantly, particle exposure can elevate the expression of ACE2, a transmembrane protein that serves as the main entry point for SARS-CoV-2 to human cells. The symptoms of COVID-19 infections may be aggravated by inhaling small aerosol particles, given that large quantities of inflammation cytokines are released when human body processes these particles. Due to the typical sub-100 nm sizes of indoor aerosol particles, it may be difficult for them to become airborne carriers of SAR-CoV-2 virion. This is also due to the fact that viruses are expelled from human respiratory tracts as droplets which contain electrolytes and cell remnants that would remain in droplet nuclei after evaporation. The coalescence of indoor aerosol particles and virus-laden droplets or droplet nuclei is plausible and the formed clusters or aggregates may protect the virions inside from radiation or toxic chemicals, although the aerodynamic characteristics of these coalescent particulate matter remain unclear. Overall, there is a scarcity of information regarding the interactions between indoor aerosol particles and virusladen droplets or droplet nuclei, and more studies are needed to validate whether those commonly occurred aerosol particles could facilitate the diffusion, transport, and persistence of SARS-CoV-2. Future efforts at prevention and control must take into consideration the potential impact of indoor aerosol particles on COVID-19 transmission and infection in enclosed indoor environments.

Acknowledgement This work was funded by the Young Talent Support Plan of Xi'an Jiaotong University.

\section{Compliance with ethical standards}

Conflict of interest The authors declare that they have no conflict of interest in this work.

\section{References}

Afshari A, Matson U, Ekberg LE (2005) Characterization of indoor sources of fine and ultrafine particles: a study conducted in a full-scale chamber. Indoor Air 15:141-150. https://doi.org/10.1 111/j.1600-0668.2005.00332.x
Alonso C, Goede DP, Morrison RB, Davies PR, Rovira A, Marthaler DG, Torremorell M (2014) Evidence of infectivity of airborne porcine epidemic diarrhea virus and detection of airborne viral RNA at long distances from infected herds. Vet Res. https:// doi.org/10.1186/s13567-014-0073-z

Amoatey P, Omidvarborna H, Baawain MS, Al-Mamun A (2020) Impact of building ventilation systems and habitual indoor incense burning on SARS-CoV-2 virus transmissions in Middle Eastern countries. Sci Total Environ. https://doi.org/10.1016/j. scitotenv.2020.139356

Azad MB, Chen Y, Gibson SB (2009) Regulation of autophagy by reactive oxygen species (ROS): implications for cancer progression and treatment. Antioxid Redox Signal 11:777-790. https://doi.org/10.1089/ars.2008.2270

Brake SJ, Barnsley K, Lu W, McAlinden KD, Eapen MS, Sohal SS (2020) Smoking upregulates angiotensin-converting enzyme-2 receptor: a potential adhesion site for novel coronavirus SARSCoV-2 (Covid-19). J Clin Med. https://doi.org/10.3390/jcm90 30841

Buonanno G, Stabile L, Morawska L (2020) Estimation of airborne viral emission: quanta emission rate of SARSCoV-2 for infection risk assessment. MedRxiv. https://doi. org/10.1101/2020.04.12.20062828

CDC (2020) Scientific Brief: SARS-CoV-2 and Potential Airborne Transmission. https://www.cdc.gov/coronavirus/2019-ncov/ more/scientific-brief-sars-cov-2.html (Accessed 17 Dec 2020)

Chauhan A, Singh RP (2020) Decline in PM2.5 concentrations over major cities around the world associated with COVID19. Environ Res 187:109634. https://doi.org/10.1016/j.envre s.2020.109634

Chen R, Hu B, Liu Y, Xu J, Yang G, Xu D, Chen C (2016) Beyond PM2.5: the role of ultrafine particles on adverse health effects of air pollution. Biochim Biophys Acta Gen Subj 1860:28442855. https://doi.org/10.1016/j.bbagen.2016.03.019

Cohen R, Sexton KG, Yeatts KB (2013) Hazard assessment of United Arab Emirates (UAE) incense smoke. Sci Total Environ 458:176-186. https://doi.org/10.1016/j.scitotenv.2013.03.101

Connolly GN, Carpenter CM, Travers MJ, Cummings KM, Hyland A, Mulcahy M, Clancy L (2009) How smoke-free laws improve air quality: a global study of Irish pubs. Nicotine Tob Res 11:600-605. https://doi.org/10.1093/ntr/ntp038

Deng X, Zhang F, Rui W, Long F, Wang L, Feng Z, Chen D, Ding W (2013) PM2.5-induced oxidative stress triggers autophagy in human lung epithelial A549 cells. Toxicol In Vitro 27:17621770. https://doi.org/10.1016/j.tiv.2013.05.004

Deng X, Zhang F, Wang L, Rui W, Long F, Zhao Y, Chen D, Ding W (2014) Airborne fine particulate matter induces multiple cell death pathways in human lung epithelial cells. Apoptosis 19:1099-1112. https://doi.org/10.1007/s10495-014-0980-5

Derudi M, Gelosa S, Sliepcevich A, Cattaneo A, Cavallo D, Rota R, Nano G (2014) Emission of air pollutants from burning candles with different composition in indoor environments. Environ Sci Pollut Res 21:4320-4330. https://doi.org/10.1007/s1135 6-013-2394-2

Duan Z, Du F, Yuan Y, Zhang Y, Yang H, Pan W (2013) Effects of PM2.5 exposure on Klebsiella pneumoniae clearance in the lungs of rats. Zhonghua Jie He He Hu Xi Za Zhi 36:836-840. https://doi.org/10.3760/cma.j.issn.1001-0939.2013.11.012

Fears AC, Klimstra WB, Duprex P, Hartman A, Weaver SC, Plante KS, Mirchandani D, Plante JA, Aguilar PV, Fernandez D, Nalca A, Totura A, Dyer D, Kearney B, Lackemeyer M, Bohannon JK, Johnson R, Garry RF, Reed DS, Roy CJ (2020) Persistence of severe acute respiratory syndrome coronavirus 2 in aerosol suspensions. Emerg Infect Dis. https://doi. org/10.3201/eid2609.201806 
Feng S, Gao D, Liao F, Zhou F, Wang X (2016) The health effects of ambient PM2.5 and potential mechanisms. Ecotoxicol Environ Saf 128:67-74. https://doi.org/10.1016/j.ecoenv.2016.01.030

Fujii T, Hayashi S, Hogg JC, Mukae H, Suwa T, Goto Y, Vincent R, van Eeden SF (2002) Interaction of alveolar macrophages and airway epithelial cells following exposure to particulate matter produces mediators that stimulate the bone marrow. Am $\mathrm{J}$ Respir Cell Mol Biol 27:34-41. https://doi.org/10.1165/ajrcm b.27.1.4787

Fujii T, Hayashi S, Hogg JC, Vincent R, Van Eeden SF (2001) Particulate matter induces cytokine expression in human bronchial epithelial cells. Am J Respir Cell Mol Biol 25:265-271. https ://doi.org/10.1165/ajrcmb.25.3.4445

Fuoco FC, Buonanno G, Stabile L, Vigo P (2014) Influential parameters on particle concentration and size distribution in the mainstream of e-cigarettes. Environ Pollut 184:523-529. https ://doi.org/10.1016/j.envpol.2013.10.010

Gast RK, Mitchell BW, Holt PS (2004) Detection of airborne Salmonella enteritidis in the environment of experimentally infected laying hens by an electrostatic sampling device. Avian Dis 48:148-154. https://doi.org/10.1637/7086

Goel A, Wathore R, Chakraborty T, Agrawal M (2017) Characteristics of exposure to particles due to incense burning inside temples in Kanpur, India. Aerosol Air Qual Res 17:608-615. https://doi.org/10.4209/aaqr.2016.04.0146

Gong WJ, Fong DYT, Wang MP, Lam TH, Chung TWH, Ho SY (2019) Increasing socioeconomic disparities in sedentary behaviors in Chinese children. BMC Public Health. https:// doi.org/10.1186/s12889-019-7092-7

Han J, Zhang X, He S, Jia P (2020) Can the coronavirus disease be transmitted from food? a review of evidence, risks, policies and knowledge gaps. Environ Chem Lett. https://doi.org/10.1007/ s10311-020-01101-x

Han Z, Weng W, Huang Q (2013) Characterizations of particle size distribution of the droplets exhaled by sneeze. J R Soc Interface. https://doi.org/10.1098/rsif.2013.0560

Havey CD, Dane AJ, Abbas-Hawks C, Voorhees KJ (2009) Detection of nitro-polycyclic aromatic hydrocarbons in mainstream and sidestream tobacco smoke using electron monochromatormass spectrometry. Environ Chem Lett 7:331-336. https://doi. org/10.1007/s10311-008-0174-x

He C, Morawska L, Taplin L (2007) Particle emission characteristics of office printers. Environ Sci Technol 41:6039-6045. https:// doi.org/10.1021/es063049z

He S, Han J (2020) Electrostatic fine particles emitted from laser printers as potential vectors for airborne transmission of COVID-19. Environ Chem Lett. https://doi.org/10.1007/s1031 1-020-01069-8

Hoffmann M, Kleine-Weber H, Schroeder S, Krueger N, Herrler T, Erichsen S, Schiergens TS, Herrler G, Wu N-H, Nitsche A, Mueller MA, Drosten C, Poehlmann S (2020) SARS-CoV-2 cell entry depends on ACE2 and TMPRSS2 and is blocked by a clinically proven protease inhibitor. Cell 181:271-280 e8. https://doi. org/10.1016/j.cell.2020.02.052

Hsueh HT, Ko TH, Chou WC, Hung WC, Chu H (2012) Health risk of aerosols and toxic metals from incense and joss paper burning. Environ Chem Lett 10:79-87. https://doi.org/10.1007/s1031 1-011-0331-5

Huang YCT, Li ZW, Harder SD, Soukup JM (2004) Apoptotic and inflammatory effects induced by different particles in human alveolar macrophages. Inhal Toxicol 16:863-878. https://doi. org/10.1080/08958370490519480

Hyland A, Travers MJ, Dresler C, Higbee C, Cummings KM (2008) A 32-country comparison of tobacco smoke derived particle levels in indoor public places. Tob Control 17:159-165. https://doi. org/10.1136/tc.2007.020479
Jia J, Xia J, Zhang R, Bai Y, Liu S, Dan M, Li T, Yan T, Chen L, Gong S, Niu P, Chen T (2019) Investigation of the impact of PM2.5 on the ciliary motion of human nasal epithelial cells. Chemosphere 233:309-318. https://doi.org/10.1016/j.chemo sphere.2019.05.274

Kang K, Kim H, Kim DD, Lee YG, Kim T (2019) Characteristics of cooking-generated PM10 and PM2.5 in residential buildings with different cooking and ventilation types. Sci Total Environ 668:56-66. https://doi.org/10.1016/j.scitotenv.2019.02.316

Klepeis NE, Nelson WC, Ott WR, Robinson JP, Tsang AM, Switzer P, Behar JV, Hern SC, Engelmann WH (2001) The National Human Activity Pattern Survey (NHAPS): a resource for assessing exposure to environmental pollutants. J Expo Sci Environ Epidemiol 11:231-252. https://doi.org/10.1038/sj.jea.7500165

Knibbs LD, He C, Duchaine C, Morawska L (2012) Vacuum cleaner emissions as a source of indoor exposure to airborne particles and bacteria. Environ Sci Technol 46:534-542. https://doi. org/10.1021/es202946w

Koivisto AJ, Hussein T, Niemela R, Tuomi T, Hameri K (2010) Impact of particle emissions of new laser printers on modeled office room. Atmos Environ 44:2140-2146. https://doi.org/10.1016/j. atmosenv.2010.02.023

Kumar P, Pirjola L, Ketzel M, Harrison RM (2013) Nanoparticle emissions from 11 non-vehicle exhaust sources-A review. Atmos Environ 67:252-277. https://doi.org/10.1016/j.atmos env.2012.11.011

Kwon HS, Ryu MH, Carlsten C (2020) Ultrafine particles: unique physicochemical properties relevant to health and disease. Exp Mol Med 52:318-328. https://doi.org/10.1038/s12276-020-0405-1

Lewis D (2020) Mounting evidence suggests coronavirus is airborne but health advice has not caught up. Nature 583:510-513. https ://doi.org/10.1038/d41586-020-02058-1

Li P, Wang L, Guo P, Yu S, Mehmood K, Wang S, Liu W, Seinfeld JH, Zhang Y, Wong D, Alapaty K, Pleim J, Mathur R (2017a) High reduction of ozone and particulate matter during the 2016 G-20 summit in Hangzhou by forced emission controls of industry and traffic. Environ Chem Lett 15:709-715. https://doi.org/10.1007/ s10311-017-0642-2

Li R, Jiang N, Liu Q, Huang J, Guo X, Liu F, Gao Z (2017b) Impact of air pollutants on outpatient visits for acute respiratory outcomes. Int J Environ Res Public Health. https://doi.org/10.3390/ ijerph14010047

Li Z, Wen Q, Zhang R (2017c) Sources, health effects and control strategies of indoor fine particulate matter (PM2.5): a review. Sci Total Environ 586:610-622. https://doi.org/10.1016/j.scito tenv.2017.02.029

Lin C, Tsai C, Sun Y, Hsieh WY, Lin C, Chen C, Lin C (2018) Instillation of particulate matter 2.5 induced acute lung injury and attenuated the injury recovery in ACE2 knockout mice. Int J Biol Sci 14:253-265. https://doi.org/10.7150/ijbs.23489

Liu H, Fan X, Wang N, Zhang Y, Yu J (2017a) Exacerbating effects of PM2.5 in OVA-sensitized and challenged mice and the expression of TRPA1 and TRPV1 proteins in lungs. J Asthma 54:807817. https://doi.org/10.1080/02770903.2016.1266495

Liu L, Wei J, Li Y, Ooi A (2017b) Evaporation and dispersion of respiratory droplets from coughing. Indoor Air 27:179-190. https ://doi.org/10.1111/ina.12297

Liu J, Chen X, Dou M, He H, Ju M, Ji S, Zhou J, Chen C, Zhang D, Miao C, Song Y (2019) Particulate matter disrupts airway epithelial barrier via oxidative stress to promote Pseudomonas aeruginosa infection. J Thorac Dis 11:2617-2627. https://doi. org/10.21037/jtd.2019.05.77

Liu WL, Zhang JF, Hashim JH, Jalaludin J, Hashim Z, Goldstein BD (2003) Mosquito coil emissions and health implications. Environ Health Perspect 111:1454-1460. https://doi.org/10.1289/ ehp.6286 
Ma Q, Qi Y, Shan Q, Liu S, He H (2020) Understanding the knowledge gaps between air pollution controls and health impacts including pathogen epidemic. Environ Res. https://doi. org/10.1016/j.envres.2020.109949

Mahabee-Gittens EM, Merianos AL, Matt GE (2020) Letter to the editor regarding: "an imperative need for research on the role of environmental factors in transmission of novel coronavirus (COVID-19)"-secondhand and thirdhand smoke as potential sources of COVID-19. Environ Sci Technol 54:5309-5310. https://doi.org/10.1021/acs.est.0c02041

Manigrasso M, Vitali M, Protano C, Avino P (2018) Ultrafine particles in domestic environments: regional doses deposited in the human respiratory system. Environ Int 118:134-145. https ://doi.org/10.1016/j.envint.2018.05.049

Manoukian A, Quivet E, Temime-Roussel B, Nicolas M, Maupetit F, Wortham H (2013) Emission characteristics of air pollutants from incense and candle burning in indoor atmospheres. Environ Sci Pollut Res 20:4659-4670. https://doi.org/10.1007/ s11356-012-1394-y

Mishra R, Krishnamoorthy P, Gangamma S, Raut AA, Kumar H (2020) Particulate matter (PM10) enhances RNA virus infection through modulation of innate immune responses. Environ Pollut. https://doi.org/10.1016/j.envpol.2020.115148

Miyata R, van Eeden SF (2011) The innate and adaptive immune response induced by alveolar macrophages exposed to ambient particulate matter. Toxicol Appl Pharmacol 257:209-226. https ://doi.org/10.1016/j.taap.2011.09.007

Moeller W, Brown DM, Kreyling WG, Stone V (2005) Ultrafine particles cause cytoskeletal dysfunctions in macrophages: role of intracellular calcium. Part Fibre Toxicol. https://doi. org/10.1186/1743-8977-2-7

Moller P, Jacobsen NR, Folkmann JK, Danielsen PH, Mikkelsen L, Hemmingsen JG, Vesterdal LK, Forchhammer L, Wallin H, Loft S (2010) Role of oxidative damage in toxicity of particulates. Free Radic Res 44:1-46. https://doi.org/10.3109/10715 760903300691

Moller W, Felten K, Sommerer K, Scheuch G, Meyer G, Meyer P, Haussinger K, Kreyling WG (2008) Deposition, retention, and translocation of ultrafine particles from the central airways and lung periphery. Am J Respir Crit Care Med 177:426-432. https ://doi.org/10.1164/rccm.200602-3010C

Morawska L, Afshari A, Bae GN, Buonanno G, Chao CYH, Hanninen O, Hofmann W, Isaxon C, Jayaratne ER, Pasanen P, Salthammer T, Waring M, Wierzbicka A (2013) Indoor aerosols: from personal exposure to risk assessment. Indoor Air 23:462-487. https://doi.org/10.1111/ina.12044

Morawska L, Johnson GR, Ristovski ZD, Hargreaves M, Mengersen K, Corbett S, Chao CYH, Li Y, Katoshevski D (2009) Size distribution and sites of origin of droplets expelled from the human respiratory tract during expiratory activities. J Aerosol Sci 40:256-269. https://doi.org/10.1016/j.jaerosci.2008.11.002

Morawska L, Milton DK (2020) It is time to address airborne transmission of COVID-19. Clin Infect Dis 9:2311-2313. https:// doi.org/10.1093/cid/ciaa939

Nicas M, Nazaroff WW, Hubbard A (2005) Toward understanding the risk of secondary airborne infection: emission of respirable pathogens. J Occup Environ Hyg 2:143-154. https://doi. org/10.1080/15459620590918466

Pagels J, Wierbicka A, Nilsson E, Isaxon C, Dahl A, Gudmundsson A, Swietlicki E, Bohgard M (2009) Chemical composition and mass emission factors of candle smoke particles. J Aerosol Sci 40:193-208. https://doi.org/10.1016/j.jaerosci.2008.10.005

Paital B, Agrawal PK (2020) Air pollution by NO(2)and PM(2.5) explains COVID-19 infection severity by overexpression of angiotensin-converting enzyme 2 in respiratory cells: a review.
Environ Chem Lett. https://doi.org/10.1007/s10311-020-01091 $-W$

Prather KA, Wang CC, Schooley RT (2020) Reducing transmission of SARS-CoV-2. Science 368:1422-1424. https://doi.org/10.1126/ science.abc6197

Qu G, Li X, Hu L, Jiang G (2020) An imperative need for research on the role of environmental factors in transmission of novel coronavirus (COVID-19). Environ Sci Technol 54:3730-3732. https ://doi.org/10.1021/acs.est.0c01102

Riva DR, Magalhaes CB, Lopes AA, Lancas T, Mauad T, Malm O, Valenca SS, Saldiva PH, Faffe DS, Zin WA (2011) Low dose of fine particulate matter (PM2.5) can induce acute oxidative stress, inflammation and pulmonary impairment in healthy mice. Inhal Toxicol 23:257-267. https://doi.org/10.3109/08958 378.2011 .566290

Rogula-Kopiec P, Rogula-Kozłowska W, Pastuszka JS, Mathews B (2019) Air pollution of beauty salons by cosmetics from the analysis of suspended particulate matter. Environ Chem Lett 17:551-558. https://doi.org/10.1007/s10311-018-0798-4

Roviello V, Roviello GN (2020) Lower COVID-19 mortality in Italian forested areas suggests immunoprotection by Mediterranean plants. Environ Chem Lett. https://doi.org/10.1007/s10311-02001063-0

Ryan E, Wright C, Gloster J (2009) Measurement of airborne foot-andmouth disease virus: preliminary evaluation of two portable air sampling devices. Vet J 179:458-461. https://doi.org/10.1016/j. tvj1.2007.10.008

Salvi D, Limaye S, Muralidharan V, Londhe J, Madas S, Juvekar S, Biswal S, Salvi S (2016) Indoor particulate matter $<2.5 \mathrm{~mm}$ in mean aerodynamic diameter and carbon monoxide levels during the burning of mosquito coils and their association with respiratory health. Chest 149:459-466. https://doi.org/10.1378/chest .14-2554

See SW, Balasubramanian R, Joshi UM (2007) Physical characteristics of nanoparticles emitted from incense smoke. Sci Technol Adv Mater 8:25-32. https://doi.org/10.1016/j.stam.2006.11.016

See SW, Balasubramanian R (2006) Physical characteristics of ultrafine particles emitted from different gas cooking methods. Aerosol Air Qual Res 6:82-92. https://doi.org/10.4209/aaqr.2006.03.0007

Semple S, Apsley A, Ibrahim TA, Turner SW, Cherrie JW (2015) Fine particulate matter concentrations in smoking households: just how much secondhand smoke do you breathe in if you live with a smoker who smokes indoors? Tob Control 24:E205-E211. https ://doi.org/10.1136/tobaccocontrol-2014-051635

Setti L, Passarini F, De Gennaro G, Barbieri P, Perrone MG, Borelli M, Palmisani J, Di Gilio A, Piscitelli P, Miani A (2020a) Airborne transmission route of COVID-19: why 2 meters/6 feet of interpersonal distance could not be enough. Int J Environ Res Pub Health. https://doi.org/10.3390/ijerph17082932

Setti L, Passarini F, De Gennaro G, Barbieri P, Perrone MG, Borelli M, Palmisani J, Di Gilio A, Torboli V, Fontana F, Clemente L, Pallavicini A, Ruscio M, Piscitelli P, Miani A (2020b) SARSCov-2RNA found on particulate matter of Bergamo in Northern Italy: first evidence. Environ Res 188:109754-109754. https:// doi.org/10.1016/j.envres.2020.109754

Smith JC, Sausville EL, Girish V, Yuan ML, Vasudevan A, John KM, Sheltzer JM (2020) Cigarette smoke exposure and inflammatory signaling increase the expression of the SARS-CoV-2 receptor ACE2 in the respiratory tract. Dev Cell 53(5):514-529 e3. https ://doi.org/10.1016/j.devcel.2020.05.012

Stadnytskyi V, Bax CE, Bax A, Anfinrud P (2020) The airborne lifetime of small speech droplets and their potential importance in SARS-CoV-2 transmission. Proc Natl Acad Sci USA 117:1187511877. https://doi.org/10.1073/pnas.2006874117

Strosnider HM, Chang HH, Darrow LA, Liu Y, Vaidyanathan A, Strickland MJ (2019) Age-specific associations of ozone and 
fine particulate matter with respiratory emergency department visits in the United States. Am J Respir Crit Care Med 199:882-890. https://doi.org/10.1164/rccm.201806-11470C

Sun S, Han J (2020) Open defecation and squat toilets, an overlooked risk of fecal transmission of COVID-19 and other pathogens in developing communities. Environ Chem Lett. https://doi. org/10.1007/s10311-020-01143-1

Tang S, Mao Y, Jones RM, Tan Q, Ji JS, Li N, Shen J, Lv Y, Pan L, Ding P, Wang X, Wang Y, MacIntyre CR, Shi X (2020) Aerosol transmission of SARS-CoV-2? Evidence, prevention and control. Environ Int. https://doi.org/10.1016/j.envin t.2020.106039

Tang T, Hurrass J, Gminski R, Mersch-Sundermann V (2012) Fine and ultrafine particles emitted from laser printers as indoor air contaminants in German offices. Environ Sci Pollut Res 19:3840-3849. https://doi.org/10.1007/s11356-011-0647-5

Torkmahalleh MA, Goldasteh I, Zhao Y, Udochu NM, Rossner A, Hopke PK, Ferro AR (2012) PM2.5 and ultrafine particles emitted during heating of commercial cooking oils. Indoor Air 22:483-491. https://doi.org/10.1111/j.1600-0668.2012.00783 . $\mathrm{x}$

van Doremalen N, Bushmaker T, Morris DH, Holbrook MG, Gamble A, Williamson BN, Tamin A, Harcourt JL, Thornburg NJ, Gerber SI, Lloyd-Smith JO, de Wit E, Munster VJ (2020) Aerosol and surface stability of SARS-CoV-2 as compared with SARSCoV-1. N Engl J Med 382:1564-1567. https://doi.org/10.1056/ NEJMc2004973

Vicente ED, Vicente AM, Evtyugina M, Calvo AI, Oduber F, Alegre CB, Castro A, Fraile R, Nunes T, Lucarelli F, Calzolai G, Nava S, Alves CA (2020) Impact of vacuum cleaning on indoor air quality. Build Environ. https://doi.org/10.1016/j.buildenv.2020.10705 9

Volesky KD, Maki A, Scherf C, Watson L, Van Ryswyk K, Fraser B, Weichenthal SA, Cassol E, Villeneuve PJ (2018) The influence of three e-cigarette models on indoor fine and ultrafine particulate matter concentrations under real-world conditions. Environ Pollut 243:882-889. https://doi.org/10.1016/j.envpol.2018.08.069

$\mathrm{Vu}$ TV, Harrison RM (2019) Chemical and physical properties of indoor aerosols. In: Harrison RM, Hester RE (eds) Indoor Air Pollution. Royal Society of Chemistry, Cambridge, pp 66-96

Vu TV, Ondracek J, Zdimal V, Schwarz J, Delgado-Saborit JM, Harrison RM (2017) Physical properties and lung deposition of particles emitted from five major indoor sources. Air Qual Atmos Health 10:1-14. https://doi.org/10.1007/s11869-016-0424-1

Wallace L, Jeong S-G, Rim D (2019) Dynamic behavior of indoor ultrafine particles (2.3-64 nm) due to burning candles in a residence. Indoor Air 29:1018-1027. https://doi.org/10.1111/ ina. 12592

Wan MP, Wu CL, Szeto GN, Chan TC, Chao CYH (2011) Ultrafine particles, and PM2.5 generated from cooking in homes. Atmos Environ 45:6141-6148. https://doi.org/10.1016/j.atmos env.2011.08.036

Wang B, Lee SC, Ho KF (2006) Chemical composition of fine particles from incense burning in a large environmental chamber. Atmos Environ 40:7858-7868. https://doi.org/10.1016/j.atmos env.2006.07.041

Wang G, Zhao J, Jiang R, Song W (2015) Rat lung response to ozone and fine particulate matter (PM2.5) exposures. Environ Toxicol Chem 30:343-356. https://doi.org/10.1002/tox.21912

Wang L, Zheng X, Stevanovic S, Xiang Z, Liu J, Shi H, Liu J, Yu M, Zhu C (2018) Characterizing pollutant emissions from mosquito repellents incenses and implications in risk assessment of human health. Chemosphere 191:962-970. https://doi.org/10.1016/j. chemosphere.2017.09.097

Wang L, Li M, Yu S, Chen X, Li Z, Zhang Y, Jiang L, Xia Y, Li J, Liu W, Li P, Lichtfouse E, Rosenfeld D, Seinfeld J (2020)
Unexpected rise of ozone in urban and rural areas, and sulfur dioxide in rural areas during the coronavirus city lockdown in Hangzhou, China: implications for air quality. Environ Chem Lett 18:1713-1723. https://doi.org/10.1007/s10311-020-01028-3 Weber S (2006) Exposure of churchgoers to airborne particles. Environ Sci Technol 40:5251-5256. https://doi.org/10.1021/es0517116

Wei J, Li Y (2015) Enhanced spread of expiratory droplets by turbulence in a cough jet. Build Environ 93:86-96. https://doi. org/10.1016/j.buildenv.2015.06.018

WHO (2014) Infection prevention and control of epidemic-and pandemic-prone acute respiratory infections in health care. https:// www.who.int/news-room/commentaries/detail/transmissionof-sars-cov-2-implications-for-infection-prevention-precaution s. (Accessed 17 December 2020)

WHO (2018) WHO global ambient air quality database. https://www. who.int/airpollution/data/en/. (Accessed 17 December 2020)

WHO (2020a) Coronavirus disease (COVID-19) pandemic. https:// www.who.int/emergencies/diseases/novel-coronavirus-2019. (Accessed 17 December 2020)

WHO (2020b) Transmission of SARS-CoV-2: implications for infection prevention precautions. https://www.who.int/news-room/ commentaries/detail/transmission-of-sars-cov-2-implicationsfor-infection-prevention-precautions. (Accessed 17 December 2020)

WHO (2020c) WHO Coronavirus Disease (COVID-19) Dashboard, Global Situation-Weekly statistics. https://covid19.who.int/. (Accessed 17 December 2020)

Wu CL, Chao CYH, Sze-To GN, Wan MP, Chan TC (2012) Ultrafine particle emissions from cigarette smouldering, incense burning, vacuum cleaner motor operation and cooking. Indoor Built Environ 21:782-796. https://doi.org/10.1177/1420326x11421356

Wu Y, Wang P, Yu S, Wang L, Li P, Li Z, Mehmood K, Liu W, Wu J, Lichtfouse E, Rosenfeld D, Seinfeld JH (2018) Residential emissions predicted as a major source of fine particulate matter in winter over the Yangtze River Delta, China. Environ Chem Lett 16:1117-1127. https://doi.org/10.1007/s10311-018-0735-6

Wu X, Nethery RC, Sabath BM, Braun D, Dominici F (2020) Exposure to air pollution and COVID-19 mortality in the United States: A nationwide cross-sectional study. medRxiv, 183: 108924

Xia X, Zhang A, Liang S, Qi Q, Jiang L, Ye Y (2017) The Association between air pollution and population health risk for respiratory infection: a case study of Shenzhen, China. Int J Environ Res Public Health. https://doi.org/10.3390/ijerph14090950

Xu C, Wu C, Yao M (2017) Fluorescent bioaerosol particles resulting from human occupancy with and without respirators. Aerosol Air Qual Res 17:198-208. https://doi.org/10.4209/aaqr.2016.09.0400

Yan X, Qiu D, Zheng S, Yang J, Sun H, Wei Y, Han J, Sun J, Su $X$ (2019) Distribution characteristics and noncarcinogenic risk assessment of culturable airborne bacteria and fungi during winter in Xinxiang, China. Environ Sci Pollut Res 26:36698-36709. https://doi.org/10.1007/s11356-019-06720-8

Yang CR, Ko TH, Lin YC, Lee SZ, Chang YF, Hsueh HT (2013) Oyster shell reduces PAHs and particulate matter from incense burning. Environ Chem Lett 11:33-40. https://doi.org/10.1007/ s10311-012-0374-2

Yang L, Cao C, Kantor ED, Nguyen LH, Zheng X, Park Y, Giovannucci EL, Matthews CE, Colditz GA, Cao Y (2019) Trends in sedentary behavior among the US population, 2001-2016. JAMA 321:1587-1597. https://doi.org/10.1001/jama.2019.3636

Yang L, Li C, Tang X (2020) The impact of PM2.5 on the host defense of respiratory system. Front Cell Dev Biol. https://doi. org/10.3389/fcell.2020.00091

Yang W, Elankumaran S, Marr LC (2011) Concentrations and size distributions of airborne influenza a viruses measured indoors at a health centre, a day-care centre and on aeroplanes. J R Soc Interface 8:1176-1184. https://doi.org/10.1098/rsif.2010.0686 
Yao Y, Pan J, Wang W, Liu Z, Kan H, Qiu Y, Meng X, Wang W (2020) Association of particulate matter pollution and case fatality rate of COVID-19 in 49 Chinese cities. Sci Total Environ 741:140396-140396. https://doi.org/10.1016/j.scito tenv.2020.140396

Yu S (2014) Water spray geoengineering to clean air pollution for mitigating haze in China's cities. Environ Chem Lett 12:109-116. https://doi.org/10.1007/s10311-013-0444-0

Zhang L, Jiang Z, Tong J, Wang Z, Han Z, Zhang J (2010) Using charcoal as base material reduces mosquito coil emissions of toxins. Indoor Air 20:176-184. https://doi.org/10.111 1/j.1600-0668.2009.00639.x

Zhao H, Li W, Gao Y, Li J, Wang H (2014) Exposure to particular matter increases susceptibility to respiratory Staphylococcus aureus infection in rats via reducing pulmonary natural killer cells. Toxicology 325:180-188. https://doi.org/10.1016/j.tox.2014.09.006

Zhao Y, Richardson B, Takle E, Chai L, Schmitt D, Xin H (2019) Airborne transmission may have played a role in the spread of 2015 highly pathogenic avian influenza outbreaks in the United States. Sci Rep. https://doi.org/10.1038/s41598-019-47788-z

Zhou R, An Q, Pan XW, Yang B, Hu J, Wang YH (2015) Higher cytotoxicity and genotoxicity of burning incense than cigarette. Environ Chem Lett 13:465-471. https://doi.org/10.1007/s1031 1-015-0521-7
Zhou Y, Fu B, Zheng X, Wang D, Zhao C, Qi Y, Sun R, Tian Z, Xu X, Wei H (2020) Pathogenic T-cells and inflammatory monocytes incite inflammatory storms in severe COVID-19 patients. Natl Sci Rev 7:998-1002. https://doi.org/10.1093/nsr/nwaa041

Zoran MA, Savastru RS, Savastru DM, Tautan MN (2020) Assessing the relationship between surface levels of PM2.5 and PM10 particulate matter impact on COVID-19 in Milan. Italy. Sci Total Environ 738:139825-139825. https://doi.org/10.1016/j.scito tenv.2020.139825

Zucker BA, Trojan S, Muller W (2000) Airborne gram-negative bacterial flora in animal houses. J Vet Med B Infect Dis Vet Public Health 47:37-46. https://doi.org/10.104 6/j.1439-0450.2000.00308.x

Zuo Z, Kuehn TH, Verma H, Kumar S, Goyal SM, Appert J, Raynor PC, Ge S, Pui DYH (2013) Association of airborne virus infectivity and survivability with its carrier particle size. Aerosol Sci Technol 47:373-382. https://doi.org/10.1080/02786 826.2012 .754841

Publisher's Note Springer Nature remains neutral with regard to jurisdictional claims in published maps and institutional affiliations. 